\title{
Contributions of regional and intercontinental transport to surface ozone in the Tokyo area
}

\author{
M. Yoshitomi ${ }^{1}$, O. Wild ${ }^{2}$, and H. Akimoto ${ }^{3}$ \\ ${ }^{1}$ Department of Earth and Planetary Sciences, Harvard University, Cambridge, MA, USA \\ ${ }^{2}$ Lancaster Environment Centre, Lancaster University, Lancaster, UK \\ ${ }^{3}$ Asia Center for Air Pollution Research, Niigata, Japan
}

Received: 16 December 2010 - Published in Atmos. Chem. Phys. Discuss.: 1 April 2011

Revised: 15 July 2011 - Accepted: 22 July 2011 - Published: 1 August 2011

\begin{abstract}
Japan lies downwind of the Asian continent and for much of the year air quality is directly influenced by emissions of ozone precursors over these heavily-populated and rapidly-industrializing regions. This study examines the extent to which oxidant transport from regional and distant anthropogenic sources influences air quality in Japan in springtime, when these contributions are largest. We find that European and North American contributions to surface ozone over Japan in spring are persistent, averaging $3.5 \pm 1.1 \mathrm{ppb}$ and $2.8 \pm 0.5 \mathrm{ppb}$ respectively, and are greatest in cold continental outflow conditions following the passage of cold fronts. Contributions from China are larger, $4.0 \pm 2.8 \mathrm{ppb}$, and more variable, as expected for a closer source region, and are generally highest near cold fronts preceding the influence of more distant sources. The stratosphere provides a varying but ever-present background of ozone of about $11.2 \pm 2.5 \mathrm{ppb}$ during spring. Local sources over Japan and Korea have a relatively small impact on mean ozone, $2.4 \pm 7.6 \mathrm{ppb}$, but this masks a strong diurnal signal, and local sources clearly dominate during episodes of high daytime ozone. By examining the meteorological mechanisms that favour transport from different source regions, we demonstrate that while maximum foreign influence generally does not occur at the same time as the greatest buildup of oxidants from local sources, it retains a significant influence under these conditions. It is thus clear that while meteorological boundaries provide some protection from foreign influence during oxidant outbreaks in Tokyo, these distant sources still make a substantial contribution to exceedance of the Japanese ozone air quality standard in springtime.
\end{abstract}

Correspondence to: $\mathrm{M}$. Yoshitomi (moeko@fas.harvard.edu)

\section{Introduction}

Air pollution is now recognized as a global issue occurring over hemispheric scales through the intercontinental transport of air pollutants such as tropospheric ozone $\left(\mathrm{O}_{3}\right)$, aerosols, mercury, and persistent organic pollutants which have atmospheric lifetimes of greater than a week (Akimoto, 2003; Holloway et al., 2003; TF-HTAP, 2007). Rapid industrialization in China, India and other Asian countries has involved increased energy consumption, affecting regionalscale air quality in Asia and beyond now and into the future (Prather et al., 2003; Dentener et al., 2006). Of particular concern is surface ozone, the abundance of which has increased to $40-50 \mathrm{ppb}$ in remote continental areas, a level at which it seriously affects air quality in many parts of the Northern Hemisphere (Pochanart et al., 2001, 2002; Lin et al., 2001; Fiore et al., 2002). Regional and intercontinental transport affect surface air quality in downwind areas (Jacob et al., 1999; Wilkening et al., 2000; Wild and Akimoto, 2001; Fiore et al., 2002; Jaffe et al., 2003), particularly at midlatitudes (Berntsen et al., 1999), and also affect the oxidizing capacity of the atmosphere (Thompson, 1992) and regional climate (Berntsen et al., 1996; Mickley et al., 1999). It is now realized that intercontinental transport may affect local $\mathrm{O}_{3}$ air quality, adding to the effects of regional transboundary transport and local photochemical formation (TF-HTAP, 2007; Fiore et al., 2009). Previous atmospheric chemistry modeling studies have shown that increased precursor emissions in Asia may be sufficient to offset reductions in American emissions and may thereby counteract the beneficial effects of air quality controls in the US (Jacob et al., 1999; Yienger et al., 2000; Heald et al., 2003). In addition, regional increases in surface background $\mathrm{O}_{3}$ and episodic exceedances of $\mathrm{O}_{3}$ air quality standards are likely to damage agriculture

Published by Copernicus Publications on behalf of the European Geosciences Union. 
and human health in China and East Asia, leading to economic damage (e.g., Mauzerall and Wang, 2001; Wang and Mauzerall, 2004) as many developed countries have already experienced (Lippmann, 1991). Thus, a quantitative understanding of the contributions of inter- and intra-continental transport may be as important for future air quality policymaking as an understanding of the effects of local emission controls (Wilkening, 2001; Fiore et al., 2003; Holloway et al., 2003).

Japan lies directly downwind of the Asian continent and is particularly susceptible to emissions from China and other Asian countries. Increases in surface $\mathrm{O}_{3}$ have been reported over Japan in the past decade (Lee et al., 1998; Ohara and Sakata, 2003; Naja and Akimoto, 2004; Tanimoto et al., 2009). This is of particular concern in the metropolitan area of Tokyo, where measurements of total photochemical oxidants $\left(\mathrm{O}_{\mathrm{x}}\right.$, predominantly $\left.\mathrm{O}_{3}\right)$ have increased since the 1980s despite strong decreases in the main precursors, nitrogen oxides $\left(\mathrm{NO}_{\mathrm{x}}=\mathrm{NO}+\mathrm{NO}_{2}\right)$ and non-methane hydrocarbons (NMHCs) (Tokyo Metropolitan Government, 2005). It is not clear to what extent increased emissions of $\mathrm{O}_{3}$ precursors over China (Irie et al., 2005; Ohara et al., 2007) have influenced this trend, but it is likely that long-range transport of $\mathrm{O}_{3}$ from the Asian continent has played a role. However, a more complete attribution of these observed changes depends on a good understanding of the factors affecting $\mathrm{O}_{3}$ over the region, and on a reliable quantification of the roles of interand intra-continental transport, stratospheric influence, and in situ formation in controlling $\mathrm{O}_{3}$, and an understanding of how these factors are controlled by meteorological processes.

The composition of air arriving over Japan is heavily influenced by regional meteorology. Direct transport of polluted air from the Asian mainland is strongest in springtime and is dominated by the passage of mid-latitude cyclones (Kaneyasu et al., 2000; Bey et al., 2001; Wild et al., 2003; Tanimoto et al., 2005). High levels of pollutants are found in the boundary layer following these frontal systems (Carmichael et al., 1998; Liu et al., 2003; Liang et al., 2004; Sawa et al., 2007), and pollutants lifted by convection and warm conveyor belts in these systems may be rapidly transported across the Pacific (Bey et al., 2001; Stohl, 2001; Heald et al., 2003; Miyazaki et al., 2003) and subsequently detected over North America (Jaffe et al., 2003; Jaeglé et al., 2003). Influence from more distant sources such as Europe may affect Japan during periods of post-frontal outflow from Asia (e.g., Liu et al., 2003; Lin et al., 2010), but the magnitude and timing of these events remains uncertain. Photochemical production of $\mathrm{O}_{3}$ is greatest in summertime, but over Japan exceedance of urban air quality standards is more common in spring, as the prevailing westerly flow brings continental air with much higher levels of $\mathrm{O}_{3}$ than is present in the tropical marine air from the Western Pacific that dominates in summer (e.g., Tanimoto et al., 2005; Yamaji et al., 2006). Continental sources may thus affect air quality attainment in Japanese cities, but the extent of their influence is not known.
This study aims to determine how local, regional and distant sources contribute to surface $\mathrm{O}_{3}$ over Japan in springtime and the extent to which they influence episodes of high $\mathrm{O}_{3}$ over the Tokyo metropolitan area. We use observations of $\mathrm{O}_{3}$ and $\mathrm{CO}$ from surface measurement sites in Japan and over the Western Pacific in spring 2001 to evaluate a global chemistry-transport model in Sect. 2 , and then use the model to determine the contribution of selected precursor emission sources to $\mathrm{O}_{3}$ over Japan during this period. In Sect. 3 we focus on the mean contribution from these sources and on their influence during key periods when $\mathrm{O}_{3}$ air quality standards are exceeded. We then examine the meteorological mechanisms that bring this air to Japan in Sect. 4, focusing on the pathways and timing of transport from the different source regions from a climatological perspective and during transport episodes of particular interest. We conclude by summarizing the influence that regional and intercontinental transport have on springtime air quality in Japan.

\section{Model and evaluation against observations}

This study uses the Frontier Research System for Global Change (FRSGC) version of the University of California, Irvine (UCI) global chemistry-transport model (CTM) (Wild and Prather, 2000) with the configuration described in Wild et al. (2003). The CTM is driven with pieced-forecast meteorological fields generated with the European Centre for Medium-Range Weather Forecasts Integrated Forecast System (ECMWF-IFS) at a spectral resolution of T159L40 at 3$\mathrm{h}$ intervals, and these data are used here at T63 $\left(1.9^{\circ} \times 1.9^{\circ}\right)$ and T21 $\left(5.6^{\circ} \times 5.6^{\circ}\right)$ resolution. The model was initialized in January 2000 and run for 16 months at T21 resolution, allowing a 1-yr spin-up and then covering winter and spring 2001. The period from January to April 2001 was repeated at the higher T63 resolution. The spring 2001 period was chosen to coincide with the NASA Transport and Chemical Evolution over the Pacific (TRACE-P) measurement campaign over the Western Pacific (Jacob et al., 2003), and previous studies using the model have been evaluated against observational data from this campaign (Wild et al., 2003). Global industrial and fossil fuel emissions of $\mathrm{O}_{3}$ precursors used in this study are taken from version 2 of the EDGAR database (Olivier et al., 1996), and emissions for East Asia are updated from Streets et al. (2003); these and other emissions are described in more detail in Wild et al. (2003).

The performance of the model during spring 2001 is evaluated with hourly observational data for surface $\mathrm{O}_{3}$ from 10 measurement sites in the Acid Deposition Monitoring Network in East Asia (EANET) (Network Center for EANET, 2005) and with $\mathrm{O}_{3}$ and $\mathrm{CO}$ from four World Meteorological Organization/Global Atmosphere Watch (WMO/GAW) stations (Tsutsumi et al., 2006). The location of these measurement sites is shown in Fig. 1 and detailed in Table 1. The sites are loosely classified here as remote, rural or suburban 
Table 1. List of EANET Measurement Sites and WMO/GAW Stations Used.

\begin{tabular}{llllrl}
\hline Site/Station & Organization & Latitude & Longitude & Altitude & Characteristics \\
\hline Rishiri & EANET & $45^{\circ} 07^{\prime} \mathrm{N}$ & $141^{\circ} 12^{\prime} \mathrm{E}$ & $40 \mathrm{~m}$ & Remote Island \\
Tappi & EANET & $41^{\circ} 15^{\prime} \mathrm{N}$ & $140^{\circ} 21^{\prime} \mathrm{E}$ & $105 \mathrm{~m}$ & Remote \\
Sadoseki & EANET & $38^{\circ} 14^{\prime} \mathrm{N}$ & $138^{\circ} 24^{\prime} \mathrm{E}$ & $110 \mathrm{~m}$ & Rural \\
Happo & EANET & $36^{\circ} 42^{\prime} \mathrm{N}$ & $137^{\circ} 48^{\prime} \mathrm{E}$ & $1850 \mathrm{~m}$ & Remote Mountain \\
Oki & EANET & $36^{\circ} 17^{\prime} \mathrm{N}$ & $133^{\circ} 11^{\prime} \mathrm{E}$ & $90 \mathrm{~m}$ & Remote Island \\
Ijira & EANET & $35^{\circ} 34^{\prime} \mathrm{N}$ & $136^{\circ} 41^{\prime} \mathrm{E}$ & $140 \mathrm{~m}$ & Suburban \\
Banryu & EANET & $34^{\circ} 41^{\prime} \mathrm{N}$ & $131^{\circ} 48^{\prime} \mathrm{E}$ & $60 \mathrm{~m}$ & Suburban \\
Yusuhara & EANET & $33^{\circ} 22^{\prime} \mathrm{N}$ & $132^{\circ} 56^{\prime} \mathrm{E}$ & $225 \mathrm{~m}$ & Rural \\
Ogasawara & EANET & $27^{\circ} 05^{\prime} \mathrm{N}$ & $142^{\circ} 13^{\prime} \mathrm{E}$ & $230 \mathrm{~m}$ & Remote Island \\
Hedo & EANET & $26^{\circ} 52^{\prime} \mathrm{N}$ & $128^{\circ} 15^{\prime} \mathrm{E}$ & $50 \mathrm{~m}$ & Remote \\
Ryori & WMO/GAW & $39^{\circ} 02^{\prime} \mathrm{N}$ & $141^{\circ} 49^{\prime} \mathrm{E}$ & $230 \mathrm{~m}$ & Rural \\
Tsukuba & WMO/GAW & $36^{\circ} 03^{\prime} \mathrm{N}$ & $140^{\circ} 08^{\prime} \mathrm{E}$ & $25 \mathrm{~m}$ & Suburban \\
Yonagunijima & WMO/GAW & $24^{\circ} 28^{\prime} \mathrm{N}$ & $123^{\circ} 01^{\prime} \mathrm{E}$ & $30 \mathrm{~m}$ & Remote Island \\
Minamitorishima & WMO/GAW & $24^{\circ} 18^{\prime} \mathrm{N}$ & $153^{\circ} 58^{\prime} \mathrm{E}$ & $8 \mathrm{~m}$ & Remote Island \\
\hline
\end{tabular}

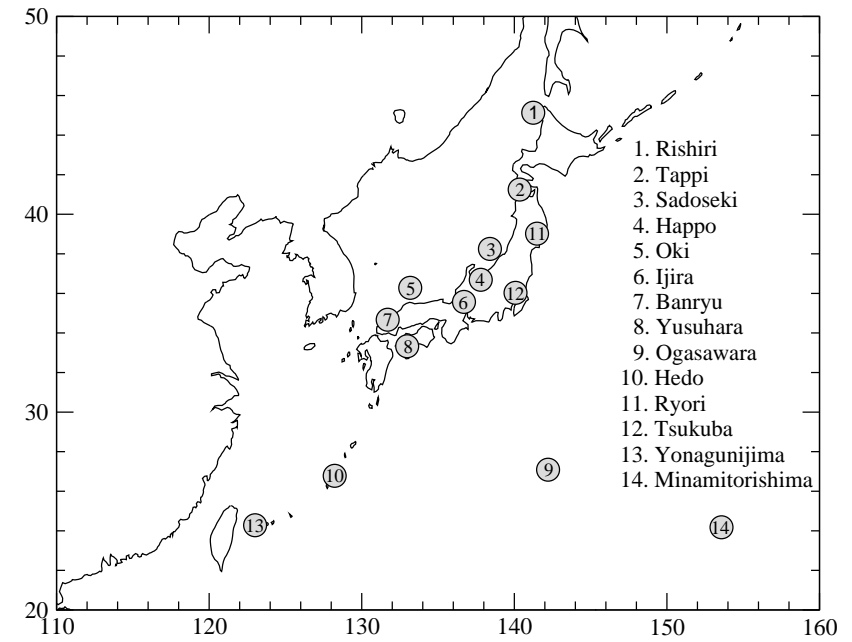

Fig. 1. Locations of EANET and WMO/GAW stations used in evaluating model performance.

based on their chemical environment. Eight clean coastal or mountain sites are categorized as remote, three sites showing strong pollution signatures are designated as suburban, and the remaining three sites showing some influence from local sources are denoted as rural. These observations are compared with hourly model results sampled from the nearest grid box at each resolution.

We first examine the model performance at remote sites which provide an effective test of the ECMWF-IFS meteorology and the ability of the CTM to correctly represent the chemical environment in clean, background conditions. Figure 2 shows the hourly timeseries of $\mathrm{O}_{3}$ and $\mathrm{CO}$ at Minamitorishima, a remote island lying almost $2000 \mathrm{~km}$ southeast of Tokyo. The prevailing influence in early spring is from continental air masses that have crossed Asia, but this flow is increasingly punctuated by the arrival of clean, marine air masses from the Central Pacific. The variability in $\mathrm{O}_{3}$ and $\mathrm{CO}$ in springtime is largely driven by the interplay between these air masses, and the location and timing of the meteorological features controlling this variability are captured very well by the ECMWF-IFS model. Surface $\mathrm{O}_{3}$ in continental air averages about $50 \mathrm{ppb}$, and in marine air averages about $15 \mathrm{ppb}$, and these abundances are reproduced well by the CTM, suggesting that the background chemical environments over the Western Pacific in spring can be represented well. The variability in $\mathrm{CO}$ is smaller, but frequent episodes of high CO reveal the passage of cold frontal systems which sweep away the clean, marine air and bring $\mathrm{CO}$ directly from the Asian continent, as previous studies have shown (Liu et al., 2003; Sawa et al., 2007). The abundance of CO in these environments is captured well by the CTM. The results are not very sensitive to model resolution at this location, although the position of meteorological features is better resolved at T63 where there is less spatial averaging of the input meteorological data, and the model bias is consequently reduced.

Polluted, continental conditions are more challenging to model but provide a more critical test of emissions, chemistry and deposition processes in the CTM. Figure 3 shows the time series of afternoon-mean surface $\mathrm{O}_{3}$ at Tsukuba, a suburban site about $50 \mathrm{~km}$ northeast of Tokyo. There is a strong diurnal variation in the observations, with very low nighttime $\mathrm{O}_{3}$ driven by both surface deposition and direct chemical removal by freshly-emitted NO. Fast chemical removal in the stable nocturnal boundary layer is not reproduced well at the coarse model resolutions used here, but is notably better at $\mathrm{T} 63$ resolution $(180 \mathrm{~km}$ scale) than at T21 $(550 \mathrm{~km}$ scale) as the artificial mixing of fresh pollutants to the model grid scale is less extensive. The Tsukuba site lies in the same model grid square as Tokyo at both resolutions, but cannot be considered representative of the whole urban 

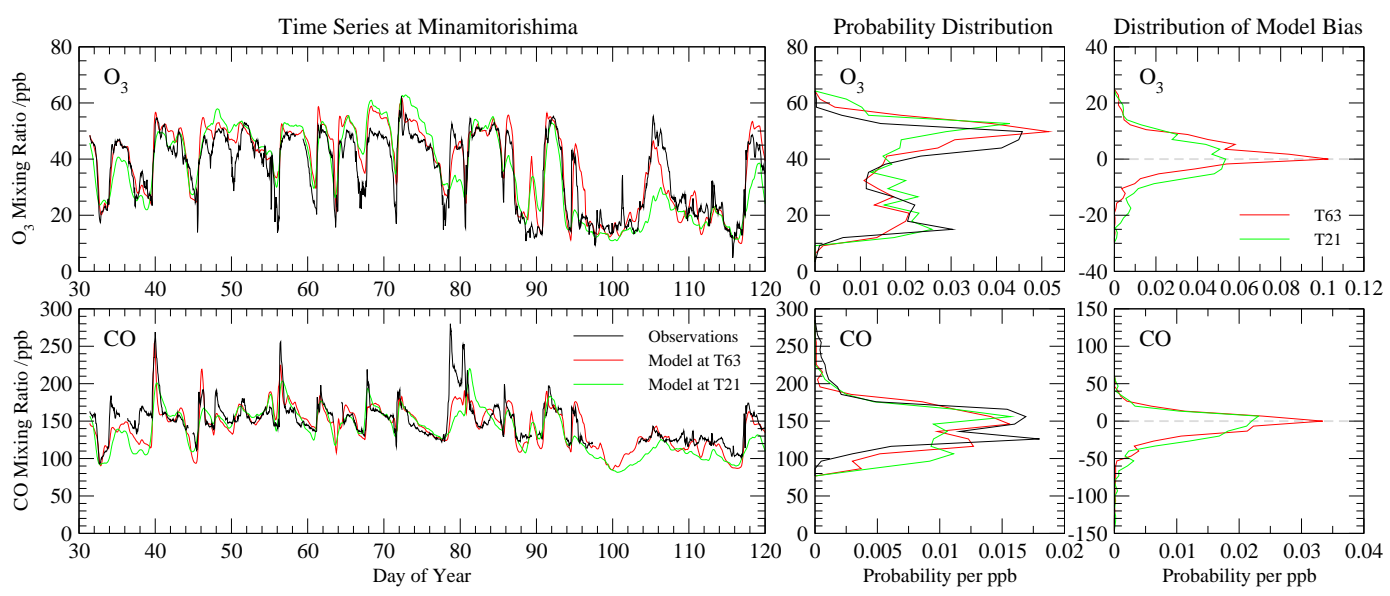

Fig. 2. Timeseries of hourly-mean surface $\mathrm{O}_{3}$ and $\mathrm{CO}$ observations at Minamitorishima WMO/GAW station in February-April 2001 and FRSGC/UCI CTM results at T21 and T63 resolution. Right-hand panels show the probability distribution over the period and the distribution of the hourly model bias at each resolution.
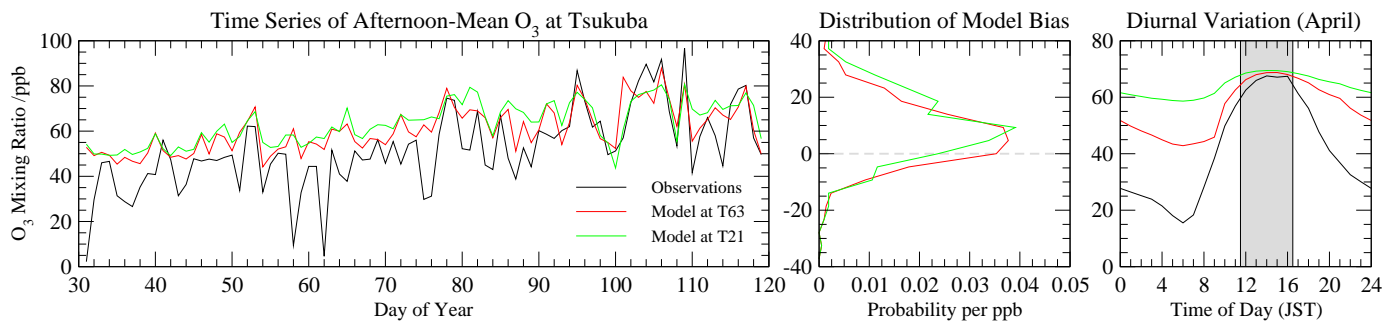

Fig. 3. Comparison of afternoon-mean $\mathrm{O}_{3}$ observations (12:00-16:00 h JST) at Tsukuba WMO/GAW station (black) with CTM results at T21 (green) and T63 (red) resolution. Right-hand panels show the distribution of the hourly model bias and the monthly mean diurnal variation in observed and modelled $\mathrm{O}_{3}$ in April.

area. To minimize the influence of nighttime removal we compare afternoon concentrations (12:00-16:00 LT) which are dominated by photochemical production of $\mathrm{O}_{3}$. These values are matched more closely by the CTM, and while there is still overestimation of all but the highest daytime levels in February and March, the main features and magnitude of urban $\mathrm{O}_{3}$ are reproduced well in April.

The performance of the model at other locations is shown in Fig. 4, and a statistical summary of the comparisons for the whole February-April 2001 period is given in Table 2. Where observational data are missing due to instrument failure or calibration errors, model data are also removed so that the sampling is identical, and the number of observations used is given in Table 2. Mean values, mean bias and rootmean-square error (RMSE) are presented for both T21 and T63 simulations. The mean bias and RMSE are generally less than $10 \mathrm{ppb}$ for the more remote measurement sites, but are substantially greater at rural and suburban sites where the efficiency of nighttime removal is not captured. The remote site at Yonagunijima lies close to Taiwan and is strongly influenced by urban emissions from Taipei at the coarse model resolutions used here; similarly Oki and the coastal sites of
Yusuhara, Sadoseki and Ryori are dominated by marine air flows but are artificially influenced by Japanese industrial regions in the model. Tappi shows little variability in $\mathrm{O}_{3}$ in air from the continent in February, but experiences high levels of $\mathrm{O}_{3}$ from Japanese sources in April as the prevailing flow changes. Island sites south of Japan such as Ogasawara, Hedo and Yonagunijima show the higher variability in $\mathrm{O}_{3}$ characteristic of frontal influence, as seen at Minamitorishima, although there is a tendency to overestimate $\mathrm{O}_{3}$ in continental air, particularly at T21 resolution. Comparison with $\mathrm{CO}$ at the WMO/GAW stations, summarized in Table 3, presents a similar picture, with synoptic features captured well, but there is a small negative mean bias, and CO is underestimated during pollution episodes and in fine-scale meteorological features such as the frontal banding seen in Fig. 2, contributing to the higher RMS error.

The model run at $\mathrm{T} 63\left(1.9^{\circ}\right)$ resolution generally shows smaller mean biases and RMS errors than the T21 $\left(5.6^{\circ}\right)$ run as meteorological features are better resolved, see Table 2 . Mean $\mathrm{O}_{3}$ levels are lower at $\mathrm{T} 63$ reflecting an overestimation of regional $\mathrm{O}_{3}$ production and background continental $\mathrm{O}_{3}$ inherent at the coarser T21 model resolution (e.g., Wild and 

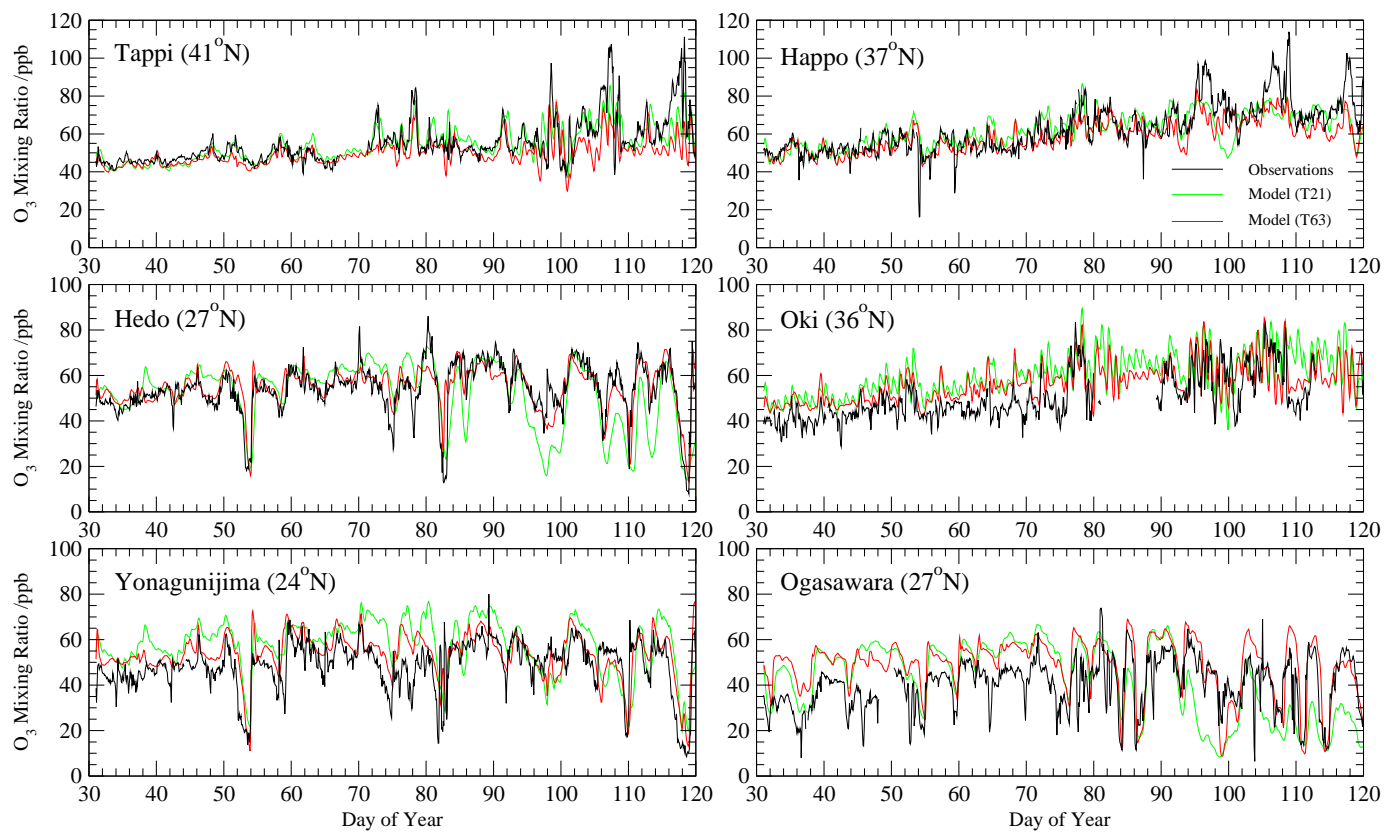

Fig. 4. Time series of hourly-mean $\mathrm{O}_{3}$ observations at selected remote EANET and WMO/GAW measurement sites in February-April 2001 (black) and FRSGC/UCI CTM results at T21 (green) and T63 (red) resolution.

Table 2. Statistical Summary of Observed and Modeled Hourly Surface $\mathrm{O}_{3}$ (in ppb) in February-April 2001.

\begin{tabular}{|c|c|c|c|c|c|c|c|c|}
\hline \multirow[t]{2}{*}{ Site/Station } & \multirow[t]{2}{*}{$n$} & \multicolumn{3}{|c|}{ Mean $\mathrm{O}_{3}( \pm 1 \sigma)$} & \multicolumn{2}{|c|}{ Mean Bias } & \multicolumn{2}{|c|}{ RMSE } \\
\hline & & Obs. & $\mathrm{T} 21$ & T63 & $\mathrm{T} 21$ & T63 & $\mathrm{T} 21$ & T63 \\
\hline \multicolumn{9}{|c|}{ Remote } \\
\hline Rishiri & 1175 & $44.1 \pm 8.4$ & $45.8 \pm 5.0$ & $44.3 \pm 3.4$ & 1.8 & 0.2 & 7.3 & 9.2 \\
\hline Tappi & 2013 & $55.0 \pm 11.6$ & $54.7 \pm 9.1$ & $49.8 \pm 6.9$ & -0.3 & -5.2 & 8.0 & 10.3 \\
\hline Happo & 2087 & $62.8 \pm 12.9$ & $62.1 \pm 8.9$ & $58.7 \pm 8.2$ & -0.6 & -4.1 & 9.8 & 9.1 \\
\hline Oki & 1730 & $50.2 \pm 10.1$ & $59.4 \pm 9.1$ & $55.8 \pm 8.3$ & 9.3 & 5.6 & 12.5 & 9.2 \\
\hline Ogasawara & 2039 & $40.0 \pm 11.3$ & $41.4 \pm 16.2$ & $48.6 \pm 12.4$ & 1.5 & 8.6 & 16.2 & 13.4 \\
\hline Hedo & 2103 & $53.9 \pm 10.9$ & $51.8 \pm 14.0$ & $54.8 \pm 9.0$ & -2.1 & 0.9 & 11.9 & 7.1 \\
\hline Yonagunijima & 2128 & $48.6 \pm 11.0$ & $57.3 \pm 11.6$ & $53.5 \pm 9.9$ & 8.7 & 4.9 & 13.7 & 9.7 \\
\hline Minamitorishima & 2096 & $35.7 \pm 13.0$ & $35.5 \pm 14.7$ & $37.7 \pm 14.0$ & -0.2 & 2.0 & 8.1 & 6.1 \\
\hline \multicolumn{9}{|c|}{ Rural } \\
\hline Ryori & 1903 & $44.9 \pm 9.4$ & $55.4 \pm 8.9$ & $54.4 \pm 7.5$ & 10.5 & 9.5 & 13.2 & 12.0 \\
\hline Sadoseki & 2103 & $48.8 \pm 15.9$ & $59.5 \pm 9.0$ & $52.8 \pm 8.1$ & 10.8 & 4.0 & 17.8 & 13.6 \\
\hline Yusuhara & 2126 & $35.1 \pm 10.6$ & $60.7 \pm 9.3$ & $57.6 \pm 8.4$ & 25.6 & 22.6 & 27.8 & 24.7 \\
\hline \multicolumn{9}{|c|}{ Suburban $^{\mathrm{a}}$} \\
\hline Tsukuba & 445 & $51.8 \pm 18.0$ & $63.2 \pm 9.2$ & $60.6 \pm 10.2$ & 11.4 & 8.8 & 18.0 & 15.8 \\
\hline Ijira & 445 & $52.9 \pm 16.2$ & $65.3 \pm 10.0$ & $60.7 \pm 8.9$ & 12.4 & 7.8 & 17.8 & 14.7 \\
\hline Banryu & 445 & $53.5 \pm 12.9$ & $66.7 \pm 11.1$ & $61.0 \pm 8.9$ & 13.2 & 7.4 & 16.1 & 12.0 \\
\hline
\end{tabular}

a Only afternoon data (12:00-16:00 JST) used at suburban sites.

Prather, 2006), and the variability is captured better. The performance is poorer at only a few locations, notably at Tappi where the site is less representative of the model grid box at T63 than at T21, and at Ogasawara, where overestimated
$\mathrm{O}_{3}$ in continental air is compensated at $\mathrm{T} 21$ by too great a marine influence in April. Note that at T21 resolution some of the sites lie in the same model grid box (e.g., Ijira, Oki and Yusuhara), and therefore show the same variation; all 
Table 3. Statistical Summary of Observed and Modeled Hourly Surface CO (in ppb) in February-April 2001.

\begin{tabular}{|c|c|c|c|c|c|c|c|c|}
\hline \multirow[t]{2}{*}{ Site/Station } & \multirow[t]{2}{*}{$n$} & \multicolumn{3}{|c|}{ Mean $\mathrm{CO}( \pm 1 \sigma)$} & \multicolumn{2}{|c|}{ Mean Bias } & \multicolumn{2}{|c|}{ RMSE } \\
\hline & & Obs. & $\mathrm{T} 21$ & T63 & $\mathrm{T} 21$ & T63 & $\mathrm{T} 21$ & $\mathrm{~T} 63$ \\
\hline Ryori & 1020 & $228.8 \pm 42.5$ & $239.2 \pm 24.0$ & $212.7 \pm 27.9$ & 10.3 & -16.1 & 41.7 & 42.5 \\
\hline Yonag & 1991 & $222.9 \pm 75.5$ & $219.2 \pm 61.1$ & $206.5 \pm 61.1$ & -3.7 & -16.4 & 66.2 & 54.8 \\
\hline Minamitorishima & 1896 & $149.7 \pm 26.3$ & $140.1 \pm 27.3$ & $144.6 \pm 25.2$ & -9.6 & -5.1 & 23.2 & 18.0 \\
\hline
\end{tabular}

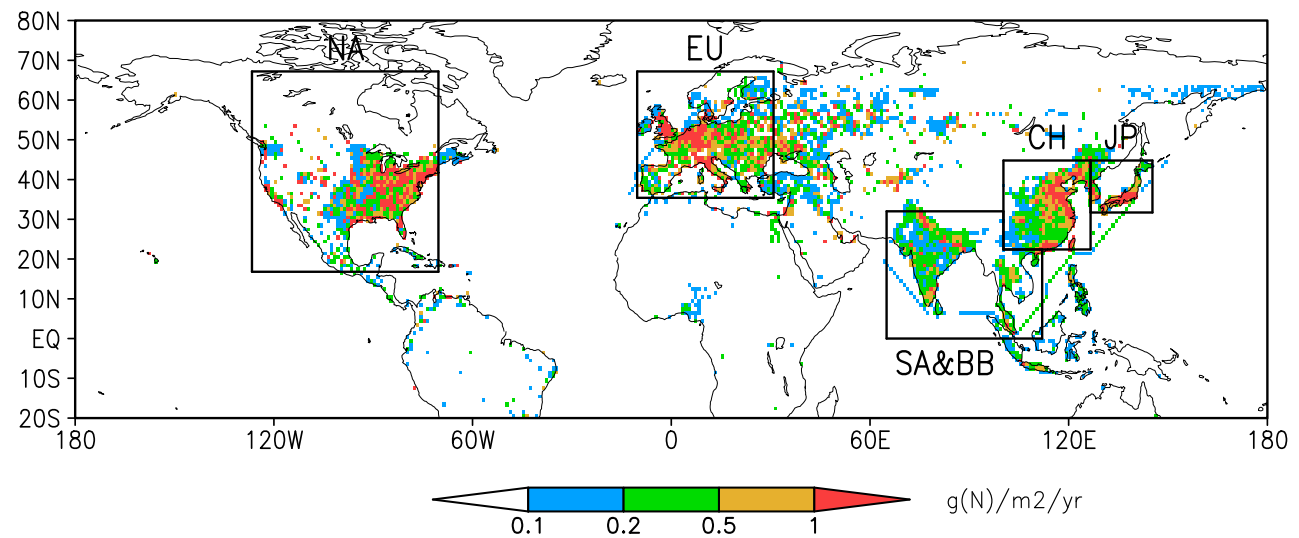

Fig. 5. Distribution of anthropogenic surface $\mathrm{NO}_{\mathrm{x}}$ emissions $\left(\mathrm{g} \mathrm{N} \mathrm{m}^{-2} \mathrm{yr}^{-1}\right)$ used in this study (Olivier et al., 1996; Streets et al., 2003) showing the principal source regions considered here.

locations lie in different grid boxes at T63. The following sections of this study focus on model simulations at T63 resolution only.

We conclude the model evaluation by examining the importance of the location of measurement sites. Two of the sites considered here, Oki and Happo, lie upwind of the major Japanese source regions, and may intercept outflow from the Asian mainland before it arrives over Tokyo. Both sites are strongly influenced by pollution from China, and $\mathrm{O}_{3}$ from this source is transported efficiently in spring (Berntsen et al., 1996; Wild and Akimoto, 2001). The sampling environment at these locations is very different, and $\mathrm{O}_{3}$ is overestimated in the marine boundary layer sampled at Oki but underestimated at the mountain site at Happo, see Table 2. However, the variations in $\mathrm{O}_{3}$ at these sites and at Tsukuba are well matched (the correlation between $\mathrm{O}_{3}$ data at Oki and Tsukuba is $r^{2}=0.46$ in observations and 0.45 in the model; for Happo and Tsukuba, $r^{2}=0.53$ and 0.52 , respectively), demonstrating that background $\mathrm{O}_{3}$ makes a substantial contribution to the variation in $\mathrm{O}_{3}$ over Tokyo. The seasonal trend at Oki is also well matched, with an increase in monthly mean $\mathrm{O}_{3}$ of $15.3 \mathrm{ppb}$ between February and April (14.6 ppb in model), but is overestimated at the higher elevation of Happo (14.3 ppb in observations, $22.3 \mathrm{ppb}$ in model) and underestimated in the more polluted conditions at Tsukuba (25.4 ppb in observations, $15.4 \mathrm{ppb}$ in model). During conditions of westerly flow there is a time lag in major features in $\mathrm{CO}$ of about $12 \mathrm{~h}$ between Oki and Tsukuba, reflecting the timescales for transport of polluted continental air between the sites.

\section{Source contributions over the Tokyo region}

We evaluate the contribution of industrial and fossil fuel sources of $\mathrm{O}_{3}$ precursors to $\mathrm{O}_{3}$ over Japan from five independent source regions: local emissions from Japan and Korea $(\mathrm{JP})$, regional emissions from China $(\mathrm{CH})$ and southern Asia (SA), and remote emissions from the major source regions of Europe (EU) and North America (NA), see Fig. 5. In addition, biomass burning sources (BB) are considered for southern Asia where peak emissions occur in the FebruaryApril period examined here (Duncan et al., 2003; Streets et al., 2003). These originate from the same region as SA emissions, but the distribution of sources is different, as industrial emissions dominate over India while biomass burning sources are greatest over Thailand and Southeast Asia. Source contributions are evaluated by removing emissions of $\mathrm{NO}_{\mathrm{x}}, \mathrm{CO}$ and VOC from each region in turn and comparing the resulting simulation with the control run. These perturbation scenarios were initialized in January 2000 and were run until the end of April 2001 at low resolution (T21), as for the control run; the January-April 2001 period was then repeated at higher resolution (T63), and the results from these runs are described here. This method provides a reasonable estimate 

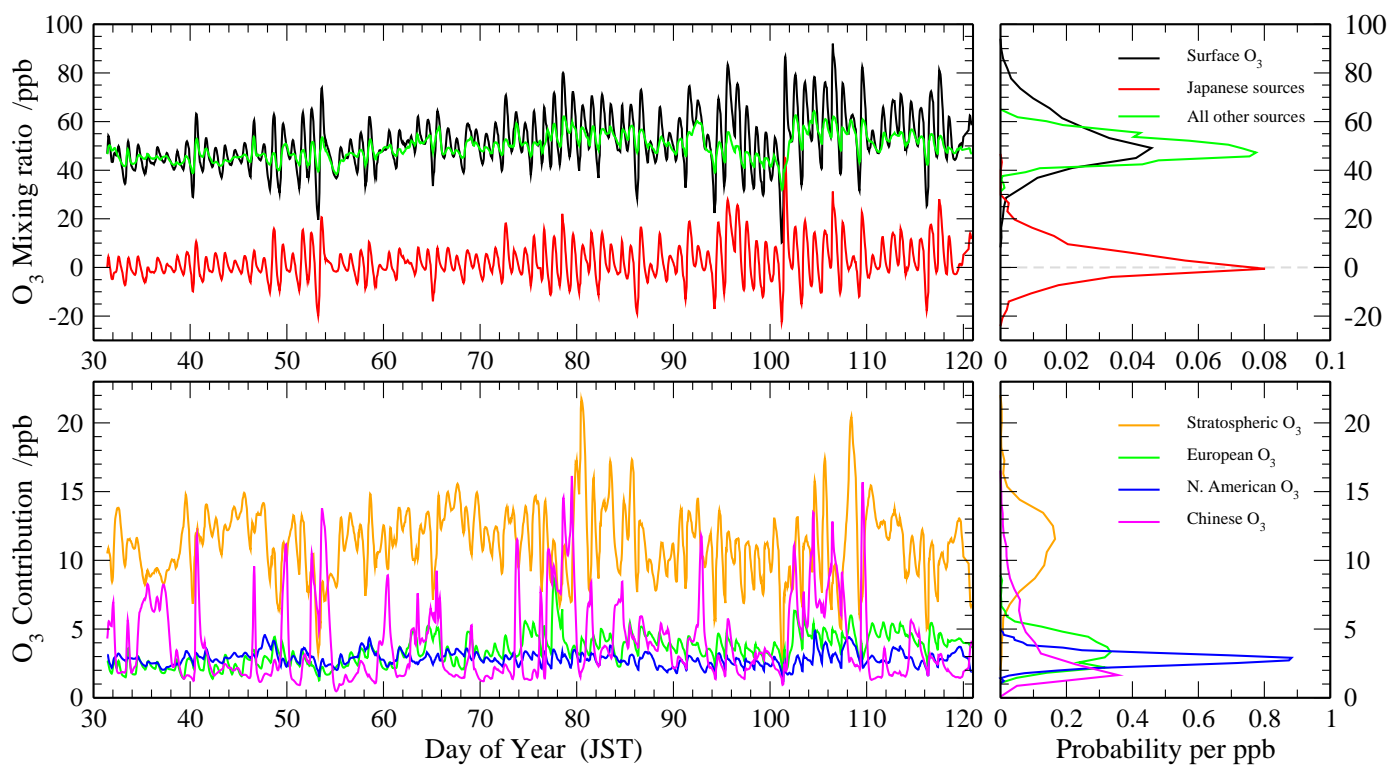

Fig. 6. Hourly mean surface $\mathrm{O}_{3}$ mixing ratios in Tokyo in February-April 2001 from the FRSGC/UCI CTM showing (a) total surface $\mathrm{O}_{3}$ (black), $\mathrm{O}_{3}$ from Japanese sources (red) and the difference between them (representing $\mathrm{O}_{3}$ from all other sources; green), and (b) contributions to $\mathrm{O}_{3}$ from Chinese (magenta), European (green) and North American (blue) sources and from the stratosphere (orange). Right-hand panels show the probability distribution over the three-month period.
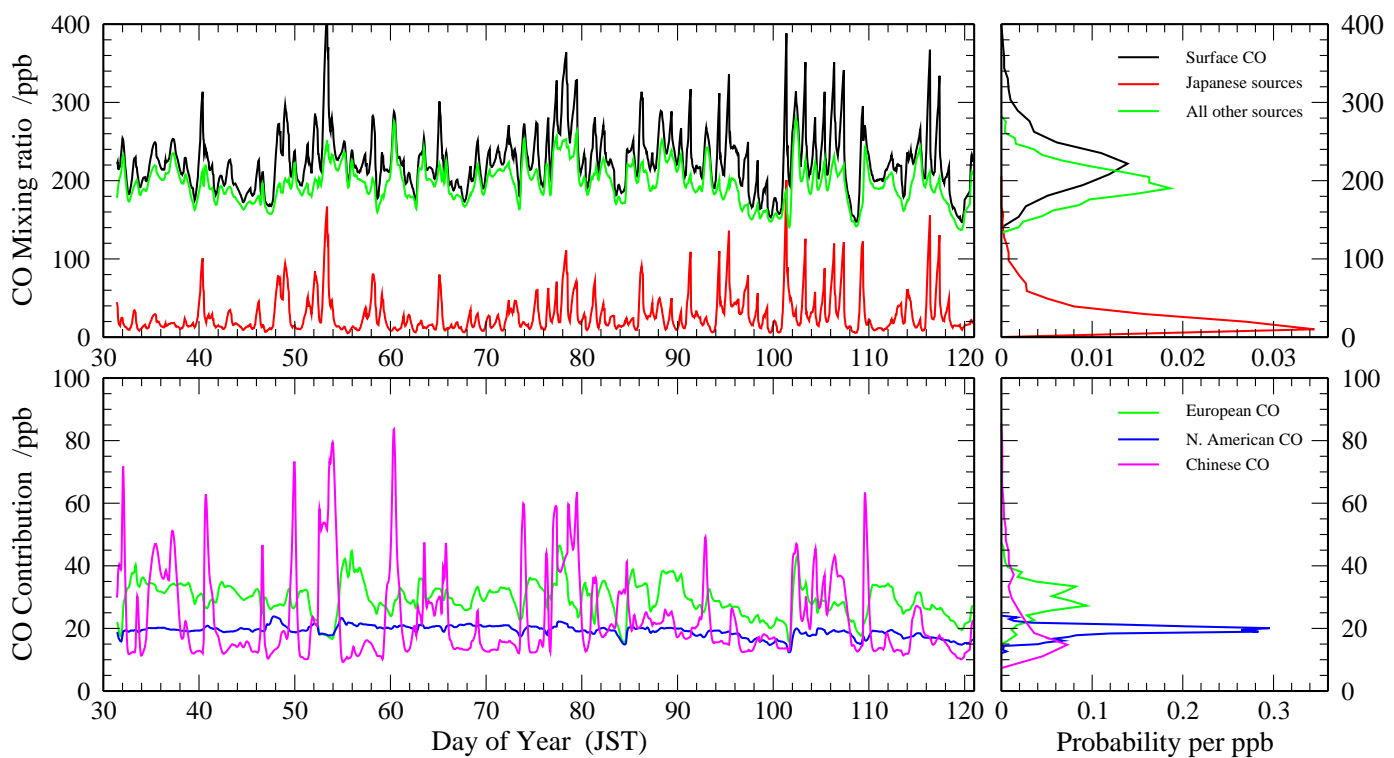

Fig. 7. Hourly mean surface CO mixing ratios in Tokyo in February-April 2001 from the FRSGC/UCI CTM showing (a) total surface $\mathrm{CO}$ (black), CO from Japanese sources (red) and background CO from other sources (green), and (b) contributions to CO from Chinese (magenta), European (green), and North American (blue) sources. Right-hand panels show the probability distribution over the three-month period.

of source contributions, although non-linearities in $\mathrm{O}_{3}$ chemistry prevent a full and accurate attribution of all sources using this method (see, e.g., Wu et al., 2009). Stratospheretroposphere exchange (STE) is also an important source of $\mathrm{O}_{3}$ in the Northern Hemisphere in springtime, and $\mathrm{O}_{3}$ from this source is diagnosed by accounting for the chemical destruction of $\mathrm{O}_{3}$ transported from the stratosphere following the method of Roelofs and Lelieveld (1997).

The modeled contribution of different source regions to surface $\mathrm{O}_{3}$ and $\mathrm{CO}$ over the Tokyo region is shown in 


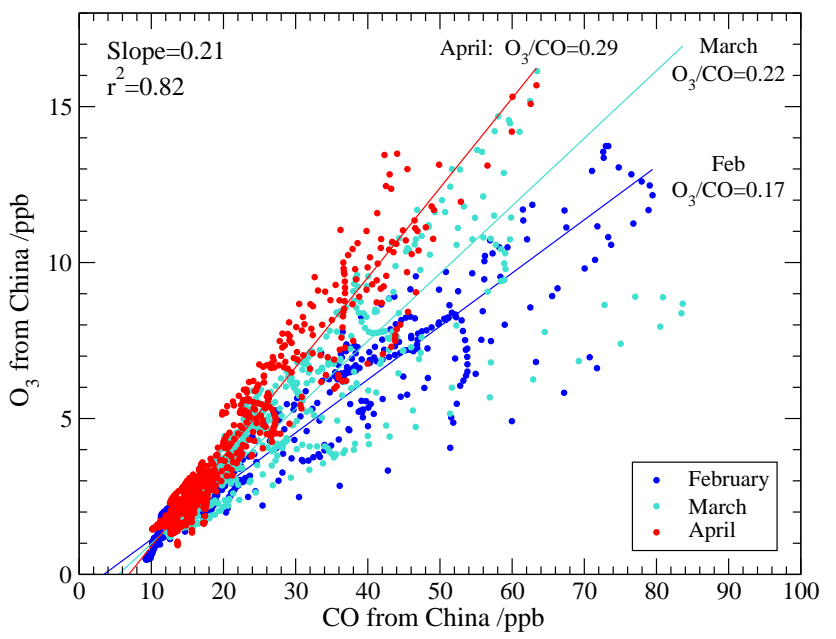

Fig. 8. Relationship between Chinese contributions to surface $\mathrm{O}_{3}$ and $\mathrm{CO}$ over Tokyo revealing the increase in photochemical activity between February and April in 2001.

Figs. 6 and 7. These results are representative of a $180 \mathrm{~km}$ grid box covering a much wider region than the Tokyo metropolitan area, and while they do not capture the heterogeneity of chemical environments close to such a major source region, or nighttime removal, the mean photochemical environment is captured sufficiently well to reproduce the day-to-day variability in $\mathrm{O}_{3}$ shown in Fig. 3. Ozone shows an upward trend over the spring period as photochemistry becomes more active, while $\mathrm{CO}$ is at its annual maximum and shows no trend over the period; however these trends are masked by large variability from both local and regional sources. This variability is driven largely by local emissions; for $\mathrm{O}_{3}$ it is dominated by the photochemical impacts of local NO emissions over Japan, which lead to production during the daytime and destruction at night, while for $\mathrm{CO}$ it is driven by local meteorology and transport processes from sources over Japan. The contribution of Japanese sources to $\mathrm{O}_{3}$ increases from February to April as photochemical activity increases, and there is also an increase for $\mathrm{CO}$, as weakening of the northwesterly winter monsoon flow allows increased influence from local sources. Chinese contributions to $\mathrm{O}_{3}$ and $\mathrm{CO}$ (averaging $4.0 \pm 2.8$ and $23 \pm 13$ ppb respectively) are strongly episodic in nature, reflecting regional meteorological patterns, and episodes occur about twice a week on average. The highest impacts reach $13-15 \mathrm{ppb}$ for $\mathrm{O}_{3}$ and 60-80 ppb for CO, and CO from Chinese sources generally exceeds that from Japanese sources during these episodes. At other times the contribution of Chinese sources is smaller than that from more distant sources like Europe and North America. Chinese contributions to $\mathrm{O}_{3}$ and $\mathrm{CO}$ are well correlated $\left(r^{2}=0.82\right)$, as shown in Fig. 8, highlighting the good relationship between emissions of $\mathrm{O}_{3}$ precursors and $\mathrm{CO}$ and the relatively short timescales for transport to Japan. The correlation is much weaker for other source regions where
$\mathrm{O}_{3}$ destruction and differing transport pathways mask the relationship. The $\mathrm{O}_{3} / \mathrm{CO}$ ratio from Chinese sources increases from 0.17 to 0.29 between February and April as photochemical activity increases, similar to that observed over the North Atlantic in outflow from North America (Parrish et al., 1993).

European and North American contributions are less variable, reflecting the greater transport distances from the source regions. European $\mathrm{O}_{3}$ contributions average $3.5 \pm$ $1.1 \mathrm{ppb}$ and rise from 2.5 to $4.1 \mathrm{ppb}$ between February and April, but the contribution from North America is relatively constant at $2.8 \pm 0.5 \mathrm{ppb}$. Contributions of European and North American sources to $\mathrm{CO}$ average 30 and $20 \mathrm{ppb}$ respectively, and the variability is again less for North American sources. The magnitude and trends of these $\mathrm{O}_{3}$ and $\mathrm{CO}$ contributions agree well with a previous study using different emission data (Wild et al., 2004) and North American CO is similar to but slightly larger than that reported by Liang et al. (2004) who found contributions of up to $15 \mathrm{ppb}$ at Ryori, Yonagunijima and Minamitorishima in spring. The contribution of industrial and biomass burning emissions from South and Southeast Asia is small at this latitude, averaging 0.5 and $0.3 \mathrm{ppb}$ for $\mathrm{O}_{3}$, respectively, and about $4 \mathrm{ppb}$ each for $\mathrm{CO}$. However, there is one episode bringing $15 \mathrm{ppb}$ of $\mathrm{CO}$ from biomass burning sources on 1 February. In contrast to these surface sources, the contribution from stratospheric $\mathrm{O}_{3}$ is large, $11.2 \pm 2.5 \mathrm{ppb}$, and is highly variable from day to day, exceeding $20 \mathrm{ppb}$ on two occasions. The stratospheric contribution is larger in March than in April, indicating that the positive trend in surface $\mathrm{O}_{3}$ seen over Japan in spring is driven largely by photochemistry, as previous observational studies have suggested (Kajii et al., 1998; Pochanart et al., 1999).

The monthly contributions of the selected source regions to $\mathrm{CO}$ and $\mathrm{O}_{3}$ over Tokyo in spring 2001 are summarized in Tables 4 and 5. Local sources of $\mathrm{CO}$ and $\mathrm{O}_{3}$ over Japan play an increasingly important role during the spring, as photochemistry picks up and long-range transport from distant source regions weakens. For $\mathrm{O}_{3}$ we consider only the afternoon hours (12:00-16:00 JST) when photochemistry is most active and the boundary layer is relatively deep to avoid the influence of nighttime removal. Local sources dominate, exceeding $20 \%$ in April, but this is only marginally larger than the influence of the stratosphere $(18 \%)$ and the combined impacts of fossil fuel sources over China, Europe and North America (18\%). These contributions are similar to those derived for March to May for the whole of Japan by Nagashima et al. (2010), who found contributions from the stratosphere of $21 \%$, from Japanese sources $22 \%$, and from Chinese sources $12 \%$, slightly greater than found here. It is thus clear that long-range transport makes a large contribution to daytime $\mathrm{O}_{3}$ over Tokyo on a mean basis throughout the spring.

Hourly source contributions are shown in Fig. 9 as a function of the total surface $\mathrm{O}_{3}$ at all times of day to demonstrate their influence during episodes of high $\mathrm{O}_{3}$ over Tokyo. There 

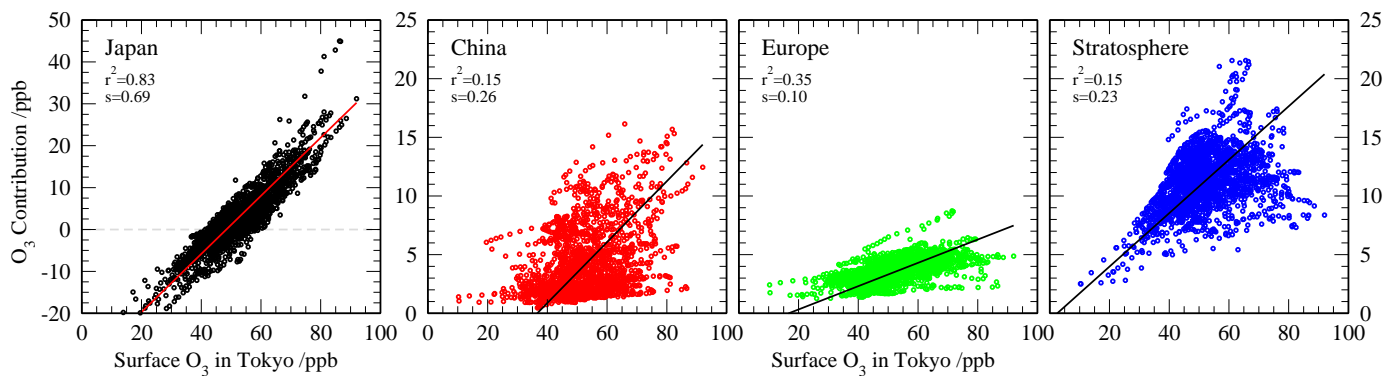

Fig. 9. Contributions of Japanese, Chinese and European industrial sources and transport from the stratosphere to hourly surface $\mathrm{O}_{3}$ over Tokyo as a function of total modelled surface $\mathrm{O}_{3}$. Graphs are labelled with the correlation coefficient $(r)$ and slope $(s)$.

Table 4. Source Contributions to Surface CO in Tokyo During Spring 2001.

\begin{tabular}{|c|c|c|c|c|c|c|c|c|}
\hline \multirow[b]{2}{*}{ JP } & \multicolumn{2}{|c|}{$\begin{array}{c}\text { Feb } \\
\operatorname{ppb}(\%)\end{array}$} & \multicolumn{2}{|c|}{$\begin{array}{c}\text { Mar } \\
\operatorname{ppb}(\%)\end{array}$} & \multicolumn{2}{|c|}{$\begin{array}{c}\text { Apr } \\
\operatorname{ppb}(\%)\end{array}$} & \multicolumn{2}{|c|}{$\begin{array}{c}\text { Feb-Apr } \\
\text { ppb }(\%)\end{array}$} \\
\hline & 26.8 & (12.1) & 24.8 & (10.7) & 34.1 & (15.4) & 28.5 & (12.7) \\
\hline $\mathrm{CH}$ & 24.3 & (11.0) & 25.3 & (11.0) & 20.7 & $(9.4)$ & 23.4 & (10.4) \\
\hline EU & 30.3 & (13.7) & 30.6 & (13.3) & 26.7 & (12.1) & 29.3 & (13.0) \\
\hline NA & 20.0 & $(9.0)$ & 20.0 & $(8.7)$ & 17.6 & (7.9) & 19.2 & $(8.5)$ \\
\hline SA & 4.0 & (1.8) & 4.4 & (1.9) & 4.1 & (1.8) & 4.2 & (1.9) \\
\hline BB & 2.5 & (1.1) & 4.8 & $(2.1)$ & 6.0 & $(2.7)$ & 4.5 & $(2.0)$ \\
\hline Total CO & 221.2 & & 231.0 & & 221.7 & & 224.8 & \\
\hline
\end{tabular}

is a very high correlation between the Japanese contribution and total surface $\mathrm{O}_{3}\left(r^{2}=0.83\right)$ indicating that local sources account for most of the variability in $\mathrm{O}_{3}$ through their control over the diurnal cycle, and they also account for much of the day-to-day variability $\left(r^{2}=0.42\right)$ reflecting their control over local photochemistry. Chinese sources show a weaker relationship $\left(r^{2}=0.15\right)$ but still contribute an average of $5.7 \mathrm{ppb}$ during periods when $\mathrm{O}_{3}$ exceeds the Japanese 1-h air quality standard of $60 \mathrm{ppb}$. European and North American sources both show a weak correlation, and contribute an average of $4.5 \mathrm{ppb}$ and $3.1 \mathrm{ppb}$ to episodes with $\mathrm{O}_{3}$ exceeding $60 \mathrm{ppb}$, respectively. These contributions from distant sources are similar to those seen in the summertime boundary layer over the US (Fiore et al., 2002). The stratospheric contribution to surface $\mathrm{O}_{3}$ lies tightly between 15 and $33 \%$ over the spring period, and although there is a notable decline when surface $\mathrm{O}_{3}$ exceeds $50 \mathrm{ppb}$, the stratosphere still contributes an average of $12.2 \mathrm{ppb}$ during $\mathrm{O}_{3}$ episodes, very similar to the local Japanese contribution of $12.6 \mathrm{ppb}$.

During the highest episodes $\mathrm{O}_{3}$ was observed to exceed $80 \mathrm{ppb}$ at Tsukuba for a total of $48 \mathrm{~h}$ over the spring period, compared with $25 \mathrm{~h}$ in the model. The contribution of each source region during the modeled exceedance periods is shown in Table 6. The six episodes shown differ substantially in nature. On 12 April (day 101), Japanese sources contributed more than $50 \%$ of the $\mathrm{O}_{3}$ peak, and industrial emissions from Chinese, European and North American sources together accounted for less than $10 \%$. How- ever, during the 20 March (day 79) and 20 April (day 109) episodes Japanese sources account for only about $25 \%$ of the $\mathrm{O}_{3}$, and Chinese sources account for more than $18 \%$. European and North American contributions remain significant during these periods, accounting for almost $10 \%$. Regional trans-boundary transport contributed significantly to the exceedance of air quality standards during these episodes. In contrast to 12 April, these two episodes were associated with large-scale anticyclonic influence over Northern Japan, and high $\mathrm{O}_{3}$ was observed at Tappi and Happo at the same time (see Fig. 4). The remaining three episodes lie between these extremes, with Japanese sources accounting for about one third of $\mathrm{O}_{3}$ and other industrial sources for 15-20\%. The stratospheric source remains a consistent contributor during these episodes, accounting for 8-12 ppb (10-15\%). Comparing contributions during episodes with mean afternoon contributions for April, it is clear that while local Japanese sources play a much bigger role than normal during episodes, contributions from distant sources are not greatly different during these periods, see Table 6 . This suggests that transboundary and intercontinental transport contribute to $\mathrm{O}_{3} \mathrm{lev}$ els over Japan during conditions that favour $\mathrm{O}_{3}$ build-up, and may thus impact attainment of air quality standards in Japan. 
Table 5. Source Contributions to Afternoon Surface $\mathrm{O}_{3}$ in Tokyo During Spring 2001.

\begin{tabular}{|c|c|c|c|c|c|c|c|c|}
\hline \multirow[b]{2}{*}{ JP } & \multicolumn{2}{|c|}{$\begin{array}{c}\text { Feb } \\
\operatorname{ppb}(\%)\end{array}$} & \multicolumn{2}{|c|}{$\begin{array}{c}\text { Mar } \\
\operatorname{ppb}(\%)\end{array}$} & \multicolumn{2}{|c|}{$\begin{array}{c}\text { Apr } \\
\operatorname{ppb}(\%)\end{array}$} & \multicolumn{2}{|c|}{$\begin{array}{c}\text { Feb-Apr } \\
\mathrm{ppb}(\%)\end{array}$} \\
\hline & 5.6 & (10.6) & 8.2 & (13.3) & 14.7 & (21.7) & 9.4 & (15.6) \\
\hline $\mathrm{CH}$ & 4.2 & $(8.0)$ & 4.6 & $(7.4)$ & 4.5 & (6.6) & 4.4 & (7.3) \\
\hline EU & 2.9 & $(5.4)$ & 4.2 & (6.9) & 4.5 & (6.6) & 3.9 & (6.4) \\
\hline NA & 3.1 & $(5.9)$ & 3.1 & (5.1) & 3.0 & $(4.4)$ & 3.0 & $(5.0)$ \\
\hline SA & 0.6 & $(1.2)$ & 0.6 & $(0.9)$ & 0.4 & $(0.6)$ & 0.5 & (0.9) \\
\hline $\mathrm{BB}$ & 0.2 & $(0.3)$ & 0.3 & $(0.5)$ & 0.4 & $(0.6)$ & 0.3 & $(0.5)$ \\
\hline Strat & 11.8 & $(22.4)$ & 13.2 & $(21.5)$ & 11.9 & $(17.5)$ & 12.2 & $(20.2)$ \\
\hline Total $\mathrm{O}_{3}$ & 52.6 & & 61.2 & & 68.1 & & 60.5 & \\
\hline
\end{tabular}

Table 6. Source Contributions to Surface $\mathrm{O}_{3}(\mathrm{ppb})$ in Tokyo During High $\mathrm{O}_{3}$ Episodes $\left(\mathrm{O}_{3}>80 \mathrm{ppb}\right)$ in Spring 2001.

\begin{tabular}{lccrrrrrrr}
\hline Date & Duration & $\mathrm{Mean}_{3}$ & $\mathrm{JP}$ & $\mathrm{CH}$ & $\mathrm{EU}$ & $\mathrm{NA}$ & $\mathrm{SA}$ & $\mathrm{BB}$ & Strat \\
\hline 20 March & $1 \mathrm{~h}$ & 80.1 & 18.5 & 14.5 & 4.5 & 3.0 & 0.4 & 0.4 & 10.4 \\
6 April & $5 \mathrm{~h}$ & 82.1 & 26.6 & 5.6 & 4.3 & 2.8 & 0.4 & 0.4 & 12.0 \\
12 April & $5 \mathrm{~h}$ & 83.8 & 42.4 & 2.2 & 2.6 & 2.0 & 0.4 & 0.5 & 8.1 \\
17 April & $8 \mathrm{~h}$ & 86.3 & 24.8 & 11.1 & 4.8 & 3.1 & 0.4 & 0.4 & 9.2 \\
20 April & $4 \mathrm{~h}$ & 81.4 & 21.3 & 14.8 & 3.2 & 2.5 & 0.3 & 0.4 & 7.6 \\
28 April & $2 \mathrm{~h}$ & 80.8 & 27.4 & 3.1 & 4.6 & 2.7 & 0.4 & 0.4 & 9.9 \\
\hline \multicolumn{7}{c}{ Contrasting episodes with monthly mean } \\
\hline Episode Mean & 83.5 & 28.1 & 8.3 & 4.0 & 2.7 & 0.4 & 0.4 & 9.4 \\
April Mean & 68.1 & 14.7 & 4.5 & 4.5 & 3.0 & 0.4 & 0.4 & 11.9 \\
\hline
\end{tabular}

\section{Transport pathways and meteorology}

The large differences seen between high $\mathrm{O}_{3}$ episodes suggest that the source contributions are very sensitive to meteorological conditions. We therefore examine how regional meteorology controls the transport of oxidants from different source regions to characterize better the composition of regional "background" air on which Japanese sources build. Meteorological conditions over East Asia in springtime are characterized by a weakening of the Siberian High that drives the northwesterly East Asian winter monsoon flow. This cold, dry continental air from over Eurasia meets warmer, more humid air over the Western Pacific, and leads to frequent and active cyclogenesis over the region. The wave cyclones that form travel northeastwards over Japan and typically increase in strength over the early spring period considered here. Continental pollutants may be rapidly swept out over the Western Pacific in the boundary layer following the associated cold fronts (e.g., Carmichael et al., 1998; Liu et al., 2003) or may be lifted into the free troposphere over the Western Pacific in the warm conveyor belt flow ahead of the front (e.g., Kaneyasu et al., 2000; Yienger et al., 2000; Miyazaki et al., 2003). Associated with these systems is a strong jet stream, and significant influx of stratospheric $\mathrm{O}_{3}$ may occur in dry air descending behind the cold front (e.g., Cooper et al., 2002). The passage of these systems leads to frequent changes in air mass origin over much of the Western Pacific, and there is a gradual transition in this variability as the marine flow strengthens. The meteorology of the region in 2001 is reasonably typical, influenced by a weak La Niña that decayed to neutral conditions in early spring (Fuelberg et al., 2003).

\subsection{Meteorological controls on source region contributions}

The juxtaposition or coalescence of air masses from different origins can be explored by examining the relationships between the contributions of different sources with time. Figure 10 shows these relationships for $\mathrm{CO}$ and $\mathrm{O}_{3}$ over Japan in February and April 2001. European and North American contributions to $\mathrm{CO}$ are well correlated, indicating that they arrive together in relatively well-mixed air masses. This signal is much stronger in March and April than in February, highlighting differences in synoptic conditions. The correlation for $\mathrm{O}_{3}$ differs from that of $\mathrm{CO}$, as $\mathrm{O}_{3}$ has a shorter lifetime and surface contributions are therefore more strongly influenced by subsidence from the free troposphere than horizontal transport. North American $\mathrm{O}_{3}$ correlates relatively well with stratospheric $\mathrm{O}_{3}$ suggesting that they arrive by similar pathways following transport and subsidence from the middle and upper troposphere. European $\mathrm{O}_{3}$ correlates with 

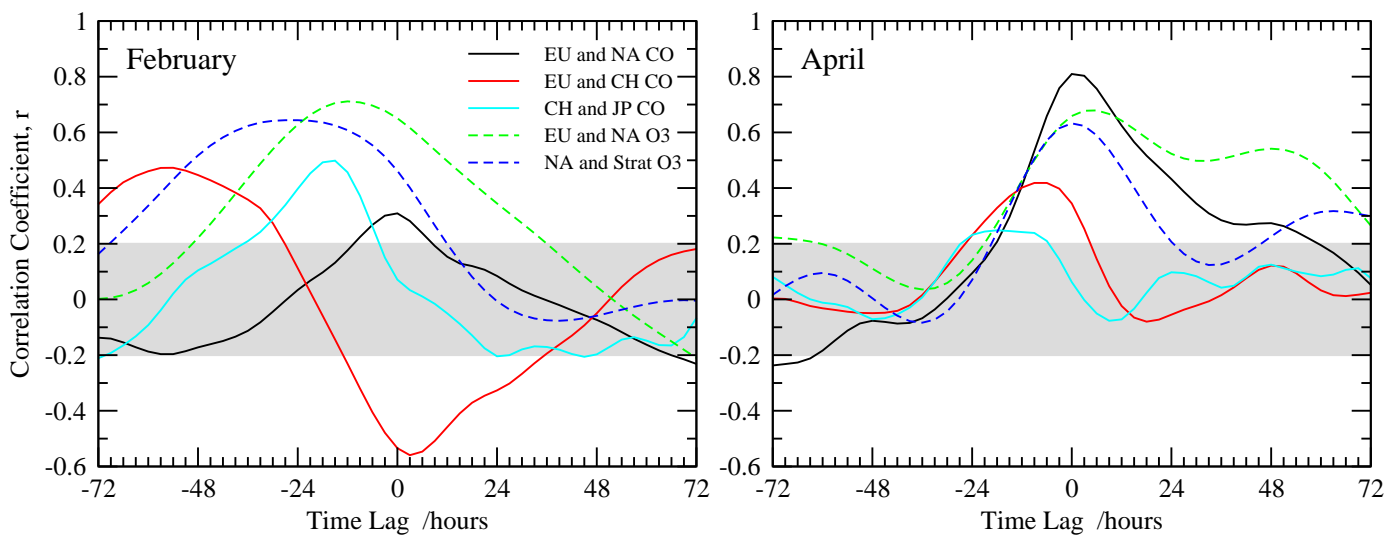

Fig. 10. Correlation between the contributions of key source regions to $\mathrm{O}_{3}$ and $\mathrm{CO}$ over Tokyo in February (left) and April (right).

(a) Chinese 03
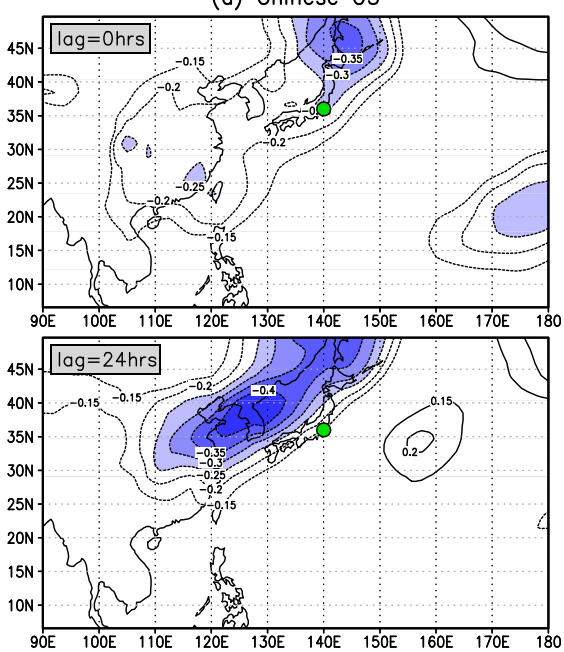

(b) European $\mathrm{CO}$
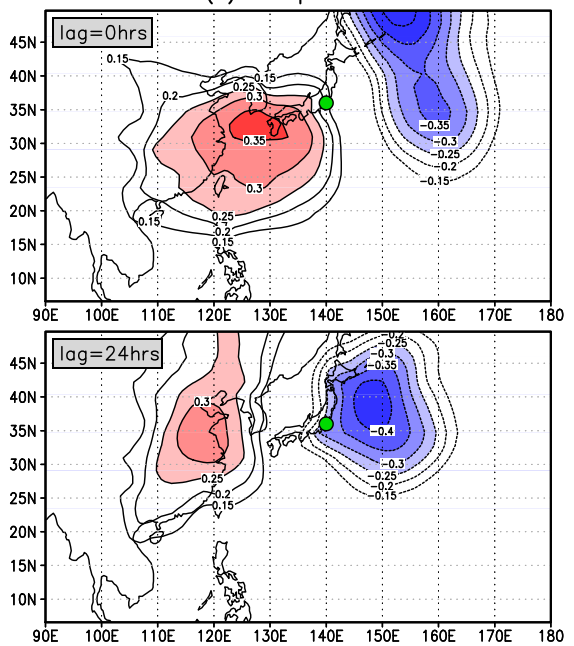

(c) Japanese $\mathrm{CO}$
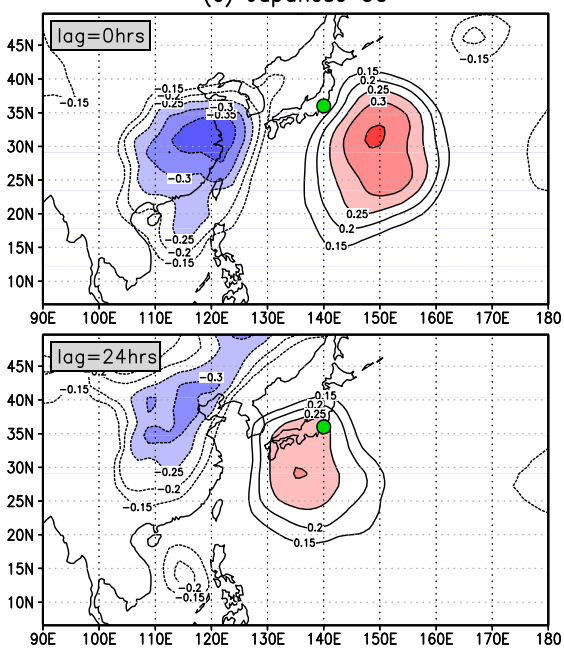

Fig. 11. Correlation between mean sea-level pressure and the contributions of (a) Chinese $\mathrm{O}_{3}$, (b) European $\mathrm{CO}$ and (c) Japanese $\mathrm{CO}$ over Tokyo (marked with a circle) in spring 2001. Positive correlations are highlighted in red and negative correlations in blue. Lower panels show the correlation coefficient lagged by $24 \mathrm{~h}$, and thus the relationship with mean sea-level pressure one day earlier.

stratospheric $\mathrm{O}_{3}$ marginally less well, consistent with transport at lower altitudes than North American air masses (Wild et al., 2004). Previous studies have suggested that European $\mathrm{CO}$ is mixed with $\mathrm{CO}$ from mainland Asian sources in postfrontal boundary layer outflow from China (Liu et al., 2003), but we find European and Chinese contributions are quite strongly anticorrelated in February, and only weakly correlated in April. This suggests that over Japan the timing of major episodes differs substantially; in February the relationship is strongest when European influence lags Chinese influence by about $48-60 \mathrm{~h}$, reflecting changes in air mass origin driven by changing synoptic systems, while in April the relationship is strongest with a lag of about $6 \mathrm{~h}$, likely reflecting Chinese influence in bands immediately behind frontal systems giving way to European influence in the following cold continental outflow.
To determine the governing meteorological mechanisms and the dominant transport patterns that bring air from different source regions to Japan in springtime we derive correlation maps of the hourly time series at Tokyo to mean sealevel pressure over the region and relate these to the prevailing meteorological conditions. Figure 11 shows this correlation map for the seasonal time series of Chinese, European and Japanese influences on Tokyo. We show examples for both $\mathrm{O}_{3}$ and $\mathrm{CO}$; the correlation patterns for both species are similar for Chinese sources, but the strong diurnal signal in $\mathrm{O}_{3}$ from Japanese sources and the lower variability from European sources give a weaker response, and we therefore show correlations for $\mathrm{CO}$ which highlight the meteorological patterns more clearly. For Chinese sources, the region of anticorrelation north of Japan indicates the climatological location of low pressure systems and associated cold fronts 

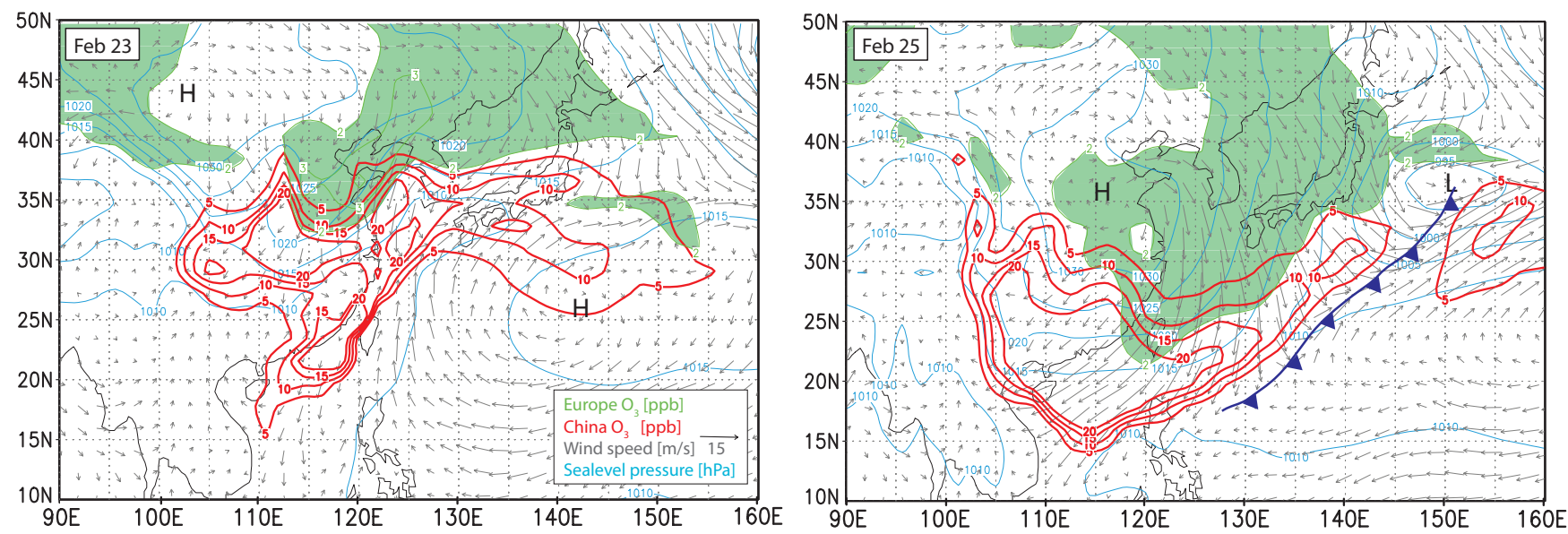

Fig. 12. Chinese and European contributions to $\mathrm{O}_{3}$ and $\mathrm{CO}$ over Japan at 00:00 UTC on 23 and 25 February 2001 showing the development and movement of air masses associated with a developing frontal system (approximate position on 25 February marked in blue).

which bring higher influence from the continent to Japan, and the classic cyclonic "comma" shape is clearly visible. Applying a 24-h lag to the time series reveals the climatological position of the low pressure one day earlier, over Korea, and demonstrates that high levels of $\mathrm{O}_{3}$ from China are associated with the passage of low pressure systems as their attendant frontal systems advance towards Japan. These patterns highlight the start of the North Pacific storm track, and show that transport of Chinese pollutants to Japan is favoured by the movement of low pressure systems northeastwards from the East China Sea. The characteristic pattern produced by this analysis is similar to that shown by Liang et al. (2005).

The correlation map for European influence is notably different and indicates that import of European air is favoured when there is higher sea-level pressure over the East China Sea along with low pressure systems northeast of Japan. This pattern is associated with northwesterly flow from Northern Eurasia to Japan, and follows on from northerly flow one day earlier. The climatological pattern represents cold outflow around the eastern side of the high pressure systems that follow the passage of wave cyclones. This is supported by an anticorrelation with humidity $\left(r^{2}=0.5\right.$, not shown) which indicates that European influence is greatest in dry continental air masses.

The correlation maps for Japanese influence are very different, and the greatest impacts on $\mathrm{CO}$ and $\mathrm{O}_{3}$ are associated with a high pressure anomaly over the northern Pacific and a low over Eastern China. This pattern reflects anticyclonic conditions over Japan governed by slow marine southwesterly flow, and these fair-weather conditions allow substantial build-up of local pollutants in the boundary layer. These conditions are relatively short-lived in spring and are typically swept away by the frontal systems associated with the next cyclone building over Eastern China.

\subsection{Case study of inflow to Japan}

While climatological patterns provide good evidence for the role of particular meteorological processes in governing transport on a seasonal basis, there is substantial variability between one synoptic system and the next. To demonstrate the key pathways for regional pollutant transport more clearly, we present a case study of the transport of continental Asian pollutants to Japan during 23-26 February 2001. Of the transport episodes we have examined, this case is reasonably typical of transport from China associated with frontal passage. Polluted air from China is transported eastwards over the Pacific, bringing high levels of $\mathrm{O}_{3}(12-14 \mathrm{ppb})$ to Japan, but is subsequently caught up in a region of cyclogenesis over the East China Sea, see Fig. 12. The passage of this cyclone along the North Pacific storm track confines oxidants in the boundary layer to a thin band along the cold front, as observed in previous studies (Kaneyasu et al., 2000; Sawa et al., 2007), with a significant proportion caught up in the warm sector ahead of it (e.g., Cooper et al., 2002). Continental boundary layer air with a greater abundance of European and North American oxidants is carried southeastwards in the cold outflow behind this front, but remains largely distinct from air of East Asian origin. The passage of this system over Japan is associated with a drop in midday temperature of $10^{\circ} \mathrm{C}$ between 23 and 25 February and a pressure drop of $14 \mathrm{hPa}$ followed by a rise of $30 \mathrm{hPa}$, see Fig. 13. The system first brings the footprint of Asian emissions to Tokyo in the warm sector, where Chinese $\mathrm{CO}$ reaches $80 \mathrm{ppb}$, and this is followed by $2-3$ days of cold, dry continental outflow from higher latitudes with little influence from Chinese sources (Chinese $\mathrm{CO}$ below $10 \mathrm{ppb}$ ). European influence is higher in the post-frontal outflow, with European $\mathrm{CO}$ rising from 15 to $45 \mathrm{ppb}$ over the period and a smaller rise for $\mathrm{O}_{3}$ of 2.2 to $3.5 \mathrm{ppb}$. While there is some mixing of air influenced by 

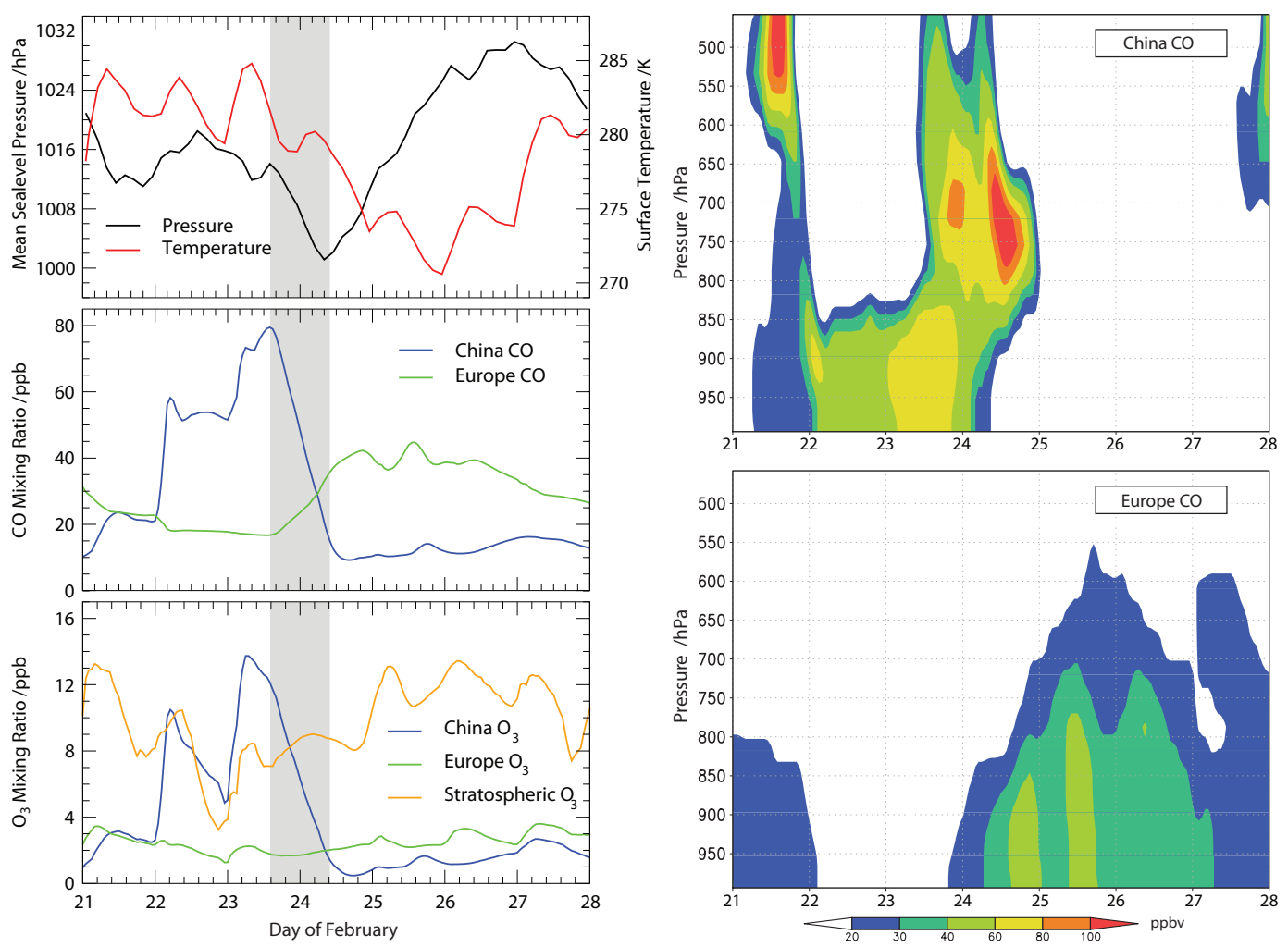

Fig. 13. Variations in surface pressure and temperature over Tokyo during the week of 21-28 February 2001, showing the passage of the frontal system shown in Fig. 12 (highlighted in grey) and the associated changes in the contribution of distant sources to $\mathrm{O}_{3}$ and $\mathrm{CO}$ (left panels). Vertical profiles of the contributions of China and Europe to CO over Tokyo between the surface and $500 \mathrm{hPa}$ (about $5 \mathrm{~km}$ ) are shown in the righthand panels, highlighting the passage of the cold front on 24 February and elevated levels of CO from China aloft.

European and East Asian sources in the post-frontal boundary layer outflow, as suggested by Liu et al. (2003), this episode demonstrates that the regional footprints can remain distinct within the timescales for transport from the continent to Japan.

The lifting of pollutants in the warm conveyor belt ahead of the cold front is clearly visible in the right panel of Fig. 13, where it brings Chinese contributions of more than $18 \mathrm{ppb}$ of $\mathrm{O}_{3}$ and $100 \mathrm{ppb}$ of $\mathrm{CO}$ at $2-3 \mathrm{~km}$ altitude as it crosses Japan. At higher altitudes in the warm sector above $4 \mathrm{~km}$ the southwesterly flow brings air from southern and southeastern Asia, with $\mathrm{O}_{3}$ reaching $12 \mathrm{ppb}$ and $\mathrm{CO}$ reaching $180 \mathrm{ppb}$, and over Japan such high contributions from south Asian industrial and biomass burning sources are only seen under these conditions. The dry intrusion behind the cold front pushes this away and brings streamers of air down from the upper troposphere with $50-60 \mathrm{ppb}$ of stratospheric $\mathrm{O}_{3}$ which persist for about a day. At the surface, stratospheric contributions average $12 \mathrm{ppb}$ in the air behind the front compared with about $6 \mathrm{ppb}$ ahead of it on 23-24 February. The lowest levels of surface $\mathrm{O}_{3}$ and $\mathrm{CO}$ over the week occur in the $24 \mathrm{~h}$ following passage of the cold front, when transport and photochemistry from local sources over Japan is suppressed and the contribution of continental sources remains low. The highest levels occur on 23 February in the $24 \mathrm{~h}$ before the system arrives, when surface $\mathrm{O}_{3}$ exceeds $60 \mathrm{ppb}$ for an 8-h period (for $5 \mathrm{~h}$ in the observations) and peaks at more than $70 \mathrm{ppb}$. Although early in the year, the fair-weather anticyclonic conditions contribute to substantial local $\mathrm{O}_{3}$ production $(20 \mathrm{ppb}$ from Japanese sources) and the southwesterly flow brings as much as $14 \mathrm{ppb} \mathrm{O}_{3}$ from Chinese sources. While this episode is not as severe as the major air quality exceedances later in spring shown in Table 6, it illustrates the transport mechanisms that allow substantial Chinese influence ahead of frontal systems where it may contribute to poor air quality over Japan. However, each synoptic system has a unique signature, and while this entrainment of continental air also occurred in the 20 March and 20 April exceedances leading to significant Chinese influence, in other cases the position of the Pacific High does not allow for this entrainment, and Chinese influence remains low, as on 12 April and 28 April. It would be valuable to explore the sensitivity of air quality exceedances in Japan to the position of these meteorological features in future work and to extend the period under consideration to account for the effects of interannual variability. 


\section{Conclusions}

We have shown how local, regional and distant sources contribute to surface $\mathrm{O}_{3}$ and $\mathrm{CO}$ over Japan in springtime and explored the transport pathways that lead to this influence. On a seasonal basis the largest contribution to daytime surface $\mathrm{O}_{3}$ is from the stratosphere $(20 \%)$, at a regional scale exceeding Japanese precursor sources (16\%) which make a relatively small contribution in February but increase rapidly through the spring as photochemistry picks up. Local sources make relatively little net contribution to day-mean $\mathrm{O}_{3}$ in this season due to strong $\mathrm{O}_{3}$ removal at nighttime over polluted emission regions. Distant anthropogenic precursor emissions over China, Europe and North America make small but significant contributions to surface $\mathrm{O}_{3}(7 \%, 6 \%$, and $5 \%$ respectively), but together these sources make up $19 \%$ of $\mathrm{O}_{3}$ over Japan, exceeding the local contribution and almost matching that from the stratosphere. The pattern for surface $\mathrm{CO}$ is similar, although Japanese sources make a smaller contribution $(13 \%)$ and distant anthropogenic sources make a larger one (32\%), with the largest effects from Europe (13\%) during the spring season.

We have shown that these source contributions are highly variable during springtime and that clear meteorological signatures can be seen in both observed and modeled $\mathrm{O}_{3}$ and $\mathrm{CO}$ at locations over the Western Pacific such as Minamitorishima. Spatial correlations with mean sea-level pressure and humidity indicate that on a climatological basis transport of pollutants from China to Japan occurs at low altitudes following the Pacific storm track, and is associated with the passage of cold fronts. Ozone contributions from Chinese sources typically reach $10-15$ ppb during these episodes, which occur on average once or twice per week. In contrast, European influence is greatest in northwesterly flow representing continental boundary layer air caught up in the cold outflow some distance behind cold fronts. While $\mathrm{O}_{3}$ and $\mathrm{CO}$ from Chinese and European sources are both transported to Japan at low levels behind these frontal systems, the influence from China is typically strongest in a band lying along the front, while that from Europe occurs later as cold continental air is entrained into the post-frontal outflow. Stratospheric contributions are largest above the capping inversions of anticyclones preceding (and following) these systems, but may reach as much as $20 \mathrm{ppb}$ at the surface on occasions. However, examination of a number of case studies indicates that there is considerable variation in transport pathways between one synoptic meteorological system and the next that is partly driven by the timing and location of cyclogenesis and partly by the location of the Pacific High. We recommend that further studies focus on a more detailed meteorological classification of these systems so that long-range impacts on atmospheric composition can be characterized more clearly.

While meteorological boundaries such as fronts provide a clear separation of air from different nearby sources, the effects of more distant sources are more uniformly distributed, and their contributions remain significant during episodes of high $\mathrm{O}_{3}$ over Tokyo in springtime. While the contribution from European and North American sources are typically close to their seasonal average during these episodes, contributions from China may often be substantially larger, although this is not always the case, depending on meteorological conditions. This study has focused on 2001, but we note that emissions of ozone precursors from Northern China are increasing due to rapid industrialization and increased vehicle ownership, and may already have increased by a factor of two since 2001 (e.g., Irie et al., 2005; Ohara et al., 2007). Our results suggest that this would account for an additional 2-4 ppb of daytime $\mathrm{O}_{3}$ over Tokyo in spring, contributing to the observed trend. The magnitude of this $\mathrm{O}_{3}$ contribution suggests that agencies regulating air quality in Japan should take account of long-range transport from the Asian mainland when examining exceedance of air quality standards in future.

Acknowledgements. This work has been partially supported by the Global Environmental Research Fund (B051 and S-7) of the Ministry of the Environment of Japan.

Edited by: T. Butler

\section{References}

Akimoto, H.: Global air quality and pollution, Science, 302, 17161719, 2003.

Akimoto, H., Mukai, H., Nishikawa, M., Murano, K., Hatakeyama, S., Liu, C.-M., Buhr, M., Hsu, K. J., Jaffe, D. A., Zhang, L., Honrath, R., Merrill, J. T., and Newell, R. E.: Long-range transport of ozone in the East Asian Pacific rim region, J. Geophys. Res., 101, 1999-2010, 1996.

Berntsen, T. K., Isaksen, I. S. A., Wang, W.-C., and Liang, X. Z.: Impacts of increased anthropogenic emissions in Asia on tropospheric ozone and climate - a global 3-D model study, Tellus, 48, 13-32, 1996.

Berntsen, T. K., Karlsdottir, S., and Jaffe, D. A.: Influence of Asian emissions on the composition of air reaching the Northwestern United States, Geophys. Res. Lett., 26, 2171-2174, 1999.

Bey, I., Jacob, D. J., Logan, J. A., and Yantosca, R. M.: Asian chemical outflow to the Pacific: origins, pathways and budgets, J. Geophys. Res., 106, 23097-23114, 2001.

Carmichael, G. R., Uno, I., Phadnes, M., Zhang, Y., and Sunwoo, Y.: Tropospheric ozone production and transport in the springtime in east Asia, J. Geophys. Res., 103, 10649-10671, 1998.

Carmichael, G. R., Tang, Y., Kurata, G., Uno, I., Streets, D. G., Thongboonchoo, N., Woo, J.-H., Guttikunda, S., White, A., Wang, T., Blake, D. R., Atlas, E., Fried, A., Potter, B., Avery, M. A., Sachse, G. W., Sandholm, S. T., Kondo, Y., Talbot, R. W., Bandy, A., Thorton, D., and Clarke, A. D.: Evaluating regional emission estimates using the TRACE-P observations, J. Geophys. Res., 108(D21), 8810, doi:10.1029/2002JD003116, 2003.

Cooper, O. R., Moody, J. L., Parrish, D. D., Trainer, M., Ryerson, T. B., Holloway, J. S., Hübler, G., Fehsenfeld, F. C., and Evans, M. J.: Trace gas composition of midlatitude cyclones over the 
western North Atlantic Ocean: A conceptual model, J. Geophys. Res., 107(D7), 4056, doi:10.1029/2001JD000901, 2002.

Dentener, F., Stevenson, D., Ellingsen, K., van Noije, T., Schultz, M., Amann, M., Atherton, C., Bell, N., Bergmann, D., Bey, I., Bouwman, L., Butler, T., Cofala, J., Collins, B., Drevet, J., Doherty, R., Eickhout, B., Eskes, H., Fiore, A., Gauss, M., Hauglustaine, D., Horowitz, L., Isaksen, I. S. A., Josse, B., Lawrence, M., Krol, M., Lamarque, J. F., Montanaro, V., Müller, J. F., Pauch, V. H., Pitari, G., Pyle, J., Rast, S., Rodriguez, J., Sanderson, M., Savage, N. H., Shindell, D., Strahan, S., Szopa, S., Sudo, K., Van Dingenen, R., Wild, O., and Zeng, G.: The global atmospheric environment for the next generation, Environ. Sci. Technol., 40, 3586-3594, 2006.

Duncan, B. N., Martin, R. V., Staudt, A. C., Yevich, R., and Logan, J. A.: Interannual and seasonal variability of biomass burning emissions constrained by satellite observations, J. Geophys. Res., 108(D9), 4040, doi:10.1029/2002JD002378, 2003.

Fiore, A. M., Jacob, D. J., Bey, I., Yantosca, R. M., Field, B. D., Fusco, A. C., and Wilkinson, J. G.: Background ozone over the United States in summer: Origin, trend, and contribution to pollution episodes, J. Geophys. Res., 107(D15), 4275, doi:10.1029/2001JD000982, 2002.

Fiore, A. M., Jacob, D. J., Liu, H., Yantosca, R. M., Fairlie, T. D., and Li, Q. B.: Variability in surface ozone background over the United States: Implications for air quality policy, J. Geophys. Res., 108, 4787, doi:10.1029/2003JD003855, 2003.

Fiore, A. M., Dentener, F. J., Wild, O., Cuvelier, C., Schultz, M. G., Hess, P., Textor, C., Schulz, M., Doherty, R. M., Horowitz, L. W., MacKenzie, I. A., Sanderson, M. G., Shindell, D. T., Stevenson, D. S., Szopa, S., Van Dingenen, R., Zeng, G., Atherton, C., Bergmann, D., Bey, I., Carmichael, G., Collins, W. J., Duncan, B. N., Faluvegi, G., Folberth, G., Gauss, M., Gong, S., Hauglustaine, D., Holloway, T., Isaksen, I. S. A., Jacob, D. J., Jonson, J. E., Kaminski, J. W., Keating, T. J., Lupu, A., Marmer, E., Montanaro, V., Park, R. J., Pitari, G., Pringle, K. J., Pyle, J. A., Schroeder, S., Vivanco, M. G., Wind, P., Wojcik, G., Wu, S., and Zuber, A.: Multi-model estimates of intercontinental sourcereceptor relationships for ozone pollution, J. Geophys. Res., 114, D04301, doi:10.1029/2008JD010816, 2009.

Fuelberg, H. E., Kiley, C. M., Hannan, J. R., Westberg, D. J., Avery, M. A., and Newell, R. E.: Meteorological conditions and transport pathways during the Transport and Chemical Evolution over the Pacific (TRACE-P) experiment, J. Geophys. Res., 108(D20), 8782, doi:10.1029/2002JD003092, 2003.

Heald, C. L., Jacob, D. J., Fiore, A. M., Emmons, L. K., Gille, J. C., Deeter, M. N., Warner, J., Edwards, D. P., Crawford, J. H., Hamlin, A. J., Sachse, G. W., Browell, E. V., Avery, M. A., Vay, S. A., Westberg, D. J., Blake, D. R., Singh, H. B., Sandholm, S. T., Talbot, R. W., and Fuelberg, H. E.: Asian outflow and transpacific transport of carbon monoxide and ozone pollution: An integrated satellite, aircraft and model perspective, J. Geophys. Res., 108(D24), 4804, doi:10.1029/2003JD003507, 2003.

Holloway, T., Fiore, A., and Galanter Hastings, M.: Intercontinental Transport of Air Pollution: Will emerging science lead to a new hemispheric treaty?, Environ. Sci. Technol., 37, 4535-4542, 2003.

Holloway, T., Sakurai, T., Han, Z., Ehlers, S., Spak, S. N., Horowitz, L. W., Carmichael, G. R., Streets, D. G., Hozumi, Y., Ueda, H., Park, S. U., Fung, C., Kajino, M., Thongboonchoo, N., Engardt,
M., Bennet, C., Hayami, H., Sartelet, K., Wang, Z., Matsuda, K., and Amann, M.: MICS-Asia II: Impact of global emissions on regional air quality in Asia, Atmos. Environ., 42, 3543-3561, 2008.

Irie, H., Sudo, K., Akimoto, H., Richter, A., Burrows, J. P., Wagner, T., Wenig, M., Beirle, S., Kondo, Y., Sinyakov, V. P., and Goutail, F.: Evaluation of long-term tropospheric $\mathrm{NO}_{2}$ data obtained by GOME over East Asia in 1996-2002, Geophys. Res. Lett., 32, L11810, doi:10.1029/2005GL022770, 2005.

Jacob, D. J., Logan, J. A., and Murti, P. P.: Effect of rising Asian emissions on surface ozone in the United States, Geophys. Res. Lett., 26, 2175-2178, 1999.

Jacob, D. J., Crawford, J. H., Kleb, M. M., Connors, V. S., Bendura, R. J., Raper, J. L., Sachse, G. W., Gille, J. C., Emmons, L., and Heald, C. L.: Transport and Chemical Evolution over the Pacific (TRACE-P) aircraft mission: Design, execution and first results, J. Geophys. Res., 108(D20), 9000, doi:10.1029/2002JD003276, 2003.

Jaeglé, L., Jaffe, D. A., Price, H. U., Weiss-Penzias, P., Palmer, P. I., Evans, M. J., Jacob, D. J., and Bey, I.: Sources and budgets for $\mathrm{CO}$ and $\mathrm{O}_{3}$ in the northeastern Pacific during the spring of 2001: Results from the PHOBEA-II Experiment, J. Geophys. Res., 108(D20), 8802, doi:10.1029/2002JD003121, 2003.

Jaffe, D. A., McKendry, I., Anderson, T., and Price, H.: Six "new" episodes of trans-Pacific transport of air pollutants, Atmos. Environ., 37(3), 391-404, 2003.

Kajii, Y., Someno, K., Tanimoto, H., Hirokawa, J., Akimoto, H., Katsuno, T., and Kawara, J.: Evidence for the seasonal variation of photochemical activity of tropospheric ozone: Continuous observation of ozone and CO at Happo, Japan, Geophys. Res. Lett., 25, 3505-3508, 1998

Kaneyasu, N., Takeuchi, K., Fujita, S., Uno, I., and Sasaki, H.: Outflow patterns of pollutants from east Asia to the North Pacific in the winter monsoon, J. Geophys. Res., 105, 17361-17377, 2000.

Lee, S.-H., Akimoto, H., Nakane, H., Kurnosenko, S., and Kinjo, Y.: Lower tropospheric ozone trend observed in 1989-1997 at Okinawa, Japan, Geophys. Res. Lett., 25(10), 1637-1640, 1998.

Liang, Q., Jaegle, L., Jaffe, D. A., Weiss-Penzias, P., Heckman, A., and Snow, J. A.: Long-range Transport to the Northeast Pacific: Seasonal variations and transport pathways of carbon monoxide, J. Geophys. Res., 109(D23), D23S07, doi:10.1029/2003JD004402, 2004

Liang, Q., Jaegle, L., and Wallace, J. M.: Meteorological indices for Asian outflow and transpacific transport on daily to interannual timescales, J. Geophys. Res., 110, D18308, doi:10.1029/2005JD005788, 2005.

Lin, C.-Y. C., Jacob, D. J., and Fiore, A. M.: Trends in exceedances of the ozone air quality standard in the continental United States, 1980-1998, Atmos. Environ., 35, 3217-3228, 2001.

Lin, M., Holloway, T., Carmichael, G. R., and Fiore, A. M.: Quantifying pollution inflow and outflow over East Asia in spring with regional and global models, Atmos. Chem. Phys., 10, 42214239, doi:10.5194/acp-10-4221-2010, 2010.

Lippmann, M.: Health effects of tropospheric ozone, Environ. Sci. Technol., 25, 1954-1962, 1991.

Liu, H., Bey, I., Yantosca, R. M., Duncan, B. N., and Sachse, G. W.: Transport pathways for Asian combustion outflow over the Pacific: Interannual and seasonal variations, J. Geophys. Res., 108, 8786, doi:10.1029/2002JD003102, 2003. 
Mauzerall, D. L. and Wang, X.: Protecting Agricultural Crops from the Effects of Tropospheric Ozone Exposure: Reconciling Science and Standard Setting in the United States, Europe and Asia, Ann. Rev. Energ. Environ., 26, 237-268, 2001.

Mauzerall, D. L., Narita, D., Akimoto, H., Horowitz, L., Walters, S., Hauglustaine, D. A., and Brasseur, G.: Seasonal Characteristics of Tropospheric Ozone Production and Mixing Ratios Over East Asia: A Global Three-dimensional Chemical Transport Model Analysis, J. Geophys. Res., 105, 17895-17910, 2000.

Mickley, L. J., Murti, P. P., Jacob, D. J., Logan, J. A., Rind, D., and Koch, D.: Radiative forcing from tropospheric ozone calculated with a unified chemistry-climate model, J. Geophys. Res., 104, 30153-30172, 1999.

Miyazaki, Y., Kondo, Y., Koike, M., Fuelberg, H. E., Kiley, C. M., Kita, K., Takegawa, N., Sachse, G. W., Flocke, F., Weinheimer, A. J., Singh, H. B., Eisele, F. L., Zondlo, M., Talbot, R. W., Sandholme, S. T., Avery, M. A., and Blake, D. R.: Synoptic-scale transport of reactive nitrogen over the western Pacific in spring, J. Geophys. Res., 108(D20), 8788, doi:10.1029/2002JD003248, 2003.

Nagashima, T., Ohara, T., Sudo, K., and Akimoto, H.: The relative importance of various source regions on East Asian surface ozone, Atmos. Chem. Phys., 10, 11305-11322, doi:10.5194/acp10-11305-2010, 2010.

Naja, M. and Akimoto, H.: Contribution of regional and longrange transport to the Asia-Pacific region: Analysis of long-term ozonesonde data over Japan, J. Geophys. Res., 109, D21306, doi:10.1029/2004JD004687, 2004.

Network Center for EANET: EANET Data on Acid Deposition in the East Asia Region, Acid Deposition and Oxidant Research Center (ADORC), Niigata, Japan, available online at: http://www.eanet.cc/, 2005.

Ohara, T. and Sakata, T.: Long-term variation of photochemical oxidants over Japan, (in Japanese), J. Jpn. Soc. Atmos. Environ., 38, 47-54, 2003.

Ohara, T., Akimoto, H., Kurokawa, J., Horii, N., Yamaji, K., Yan, X., and Hayasaka, T.: An Asian emission inventory of anthropogenic emission sources for the period 1980-2020, Atmos. Chem. Phys., 7, 4419-4444, doi:10.5194/acp-7-4419-2007, 2007.

Olivier, J. G. J., Bouwman, A. F., van der Maas, C. W. M., Berdowski, J. J. M., Veldt, C., Bloos, J. P. J., Visschedijk, A. J. H., Zandveld, P. Y. J., and Haverlag, J. L.: Description of EDGAR Version 2.0, RIVM/TNO report 771060 002, RIVM, Bilthoven, The Netherlands, 1996.

Parrish, D. D., Holloway, J. S., Trainer, M., Murphy, P. C., Fehsenfeld, F. C., and Forbes, G. L.: Export of North American ozone pollution to the North Atlantic Ocean, Science, 259, 1436-1439, 1993.

Pochanart, P., Hirokawa, J., Kajii, Y., Akimoto, H., and Nakao, M.: Influence of regional-scale anthropogenic activity in northeast Asia on seasonal variations of surface ozone and carbon monoxide observed at Oki, Japan, J. Geophys. Res., 104(D20), 36213361, 1999.

Pochanart, P., Akimoto, H., Maksyutov, S., and Staehelin, J.: Surface ozone at the Swiss Alpine site Arosa: the hemispheric background and the influence of large-scale anthropogenic emissions, Atmos. Environ. 35, 5553-5566, 2001.

Pochanart, P., Akimoto, H., Kinjo, Y., and Tanimoto, H.: Surface ozone at four remote island sites and the preliminary assessment of exceedances of its critical level in Japan, Atmos. Environ., 36, 4235-4250, 2002.

Prather, M. and Ehhalt, D.: Atmospheric Chemistry and Greenhouse Gases, in Climate Change 2001: The Scientific Basis, edited by: Houghton, J. T., Ding, Y., and Griggs, D. J., 239-287, Cambridge Univ. Press, Cambridge, 2001.

Prather, M., Gauss, M., Berntsen, T., Isaksen, I., Sundet, J., Bey, I., Brasseur, G., Dentener, F., Derwent, R., Stevenson, D., Grenfell, L., Hauglustaine, D., Horowitz, L., Jacob, D., Mickley, L., Lawrence, M., von Kuhlmann, R., Muller, J.-F., Pitari, G., Rogers, H., Johnson, M., Pyle, J., Law, K., van Weele, M., and Wild, O.: Fresh air in the 21 st century?, Geophys. Res. Lett., 30(2), 1100, doi:10.1029/2002GL016285, 2003.

Roelofs, G. J. and Lelieveld, J.: Model study of the influence of cross-tropopause ozone transports on tropospheric ozone levels, Tellus, Ser. B, 49, 38-55, 1997.

Sawa, Y., Tanimoto, H., Yonemura, S., Matsueda, H., Wada, A., Taguchi, S., Hayasaka, T., Tsuruta, H., Tohjima, Y., Mukai, H., Kikuchi, N., Katagiri, S., and Tsuboi, K.: Widespread pollution events of carbon monoxide observed over the western North Pacific during the East Asian Regional Experiment (EAREX) 2005 campaign, J. Geophys. Res., 112, D22S26, doi:10.1029/2006JD008055, 2007.

Stohl, A.: A 1-year Lagrangian "climatology" of airstreams in the Northern Hemisphere troposphere and lowermost stratosphere, J. Geophys. Res., 106, 7263-7279, 2001.

Streets, D. G., Yarber, K. F., Woo, J.-H., and Carmichael, G. R.: Biomass Burning in Asia: Annual and seasonal estimates and atmospheric emissions, Global Biogeochem. Cycles, 17(4), 1099, doi:10.1029/2003GB002040, 2003.

Tanimoto, H., Sawa, Y., Matsueda, H., Uno, I., Ohara, T., Yamaji, K., Kurokawa, J., and Yonemura, S.: Significant latitudinal gradient in the surface ozone spring maximum over East Asia, Geophys. Res. Lett., 32, L21805, doi:10.1029/2005GL023514, 2005.

Tanimoto, H., Ohara, T., and Uno, I.: Asian anthropogenic emissions and decadal trends in springtime ozone over Japan: 1998-2007, Geophys. Res. Lett., 36, L23802 doi:10.1029/2009GL041382, 2009.

Task Force on Hemispheric Transport of Air Pollutants (TF-HTAP): Hemispheric Transport of Air Pollution 2007, Air Pollut. Stud. 16, edited by: Keating, T. J. and Zuber, A., UNECE, Geneva, Switzerland, available at: http://www.htap.org/, 2007.

Thompson, A. M.: The oxidising capacity of the earth's atmosphere: Probable past and future changes, Science, 256, 11571165, 1992.

Tokyo Metropolitan Government: Report of the Committee for Photochemical Oxidant and its Control, Tokyo Metropolitan Government, Tokyo, Japan, 2005.

Tsutsumi, Y., Mori, K., Ikegami, M., Tashiro, T., and Tsuboi, K.: Long-term trends of greenhouse gases in regional and background events observed during 1998-2004 at Yonagunijima located to the east of the Asian continent, Atmos. Environ., 40, 5868-5879, 2006.

Uno, I., Jang, E.-S., Murano, K., Shimohara, T., Oishi, O., Utsunomiya, A., Hatakeyama, S., Tang, X., and Kim, Y.-P.: Wintertime intermittent transboundary air pollution over East Asia simulated by a long-range transport model, Global Environ. Res., 4, 3-12, 2000. 
Wang, X. and Mauzerall, D. L.: Characterizing Distributions of Surface Ozone and its Impact on Grain Production in China, Japan and South Korea: 1990 and 2020, Atmos. Environ., 38, 43834402, 2004.

Wild, O. and Akimoto, H.: Intercontinental transport of ozone and its precursors in a 3-D global model, J. Geophys. Res., 106, 27729-27744, 2001

Wild, O. and Prather, M. J.: Excitation of the primary tropospheric chemical mode in a global 3-D model, J. Geophys. Res., 105, 24647-24660, 2000.

Wild, O. and Prather, M. J.: Global tropospheric ozone modeling: Quantifying errors due to grid resolution, J. Geophys. Res., 111, D11305, doi:10.1029/2005JD006605, 2006.

Wild, O., Sundet, J. K., Prather, M. J., Isaksen, I. S. A., Akimoto, H., Browell, E. V., and Oltmans, S. J.: CTM Ozone Simulations for Spring 2001 over the Western Pacific: Comparisons with TRACE-P lidar, ozonesondes and TOMS columns, J. Geophys. Res., 108, 8826, doi:10.1029/2002JD003283, 2003.

Wild, O., Pochanart, P., and Akimoto, H.: Trans-Eurasian transport of ozone and its precursors, J. Geophys. Res., 109, D11302, doi:10.1029/2003JD004501, 2004.

Wilkening, K. E., Barrie, L., and Engle, M.: Trans-Pacific air pollution, Science, 290, 65-67, 2000.
Wilkening, K. E.: Trans-Pacific air pollution: scientific evidence and political implication, Water Air Soil Pollut., 130(1-4), 18251830, 2001.

Wu, S., Duncan, B. N., Jacob, D. J., Fiore, A. M., and Wild, O.: Chemical nonlinearities in relating intercontinental ozone pollution to anthropogenic emissions, Geophys. Res. Lett., 36, L05806, doi:10.1029/2008GL036607, 2009.

Yamaji, K., Ohara, T., Uno, I., Tanimoto, H., Kurokawa, J., and Akimoto, H.: Analysis of the seasonal variation of ozone in the boundary layer in east Asia using the Community Multi-scale Air Quality model: What controls surface ozone levels over Japan?, Atmos. Environ., 40(10), 1856-1868, doi:10.1016/j.atmosenv.2005.10.067, 2006.

Yienger, J. J., Klonecki, A. A., Levy II, H., Moxim, W. J., and Carmichael, G. R.: An evaluation of chemistry's role in the winter-spring ozone maximum found in the northern midlatitude free troposphere, J. Geophys. Res., 104, 3655-3667, 1999.

Yienger, J. J., Galanter, M., Holloway, T. A., Phadnis, M. J., Guttikunda, S. K., Carmichael, G. R., Moxim, W. J., and Levy II, H.: The episodic nature of air pollution transport from Asia to North America, J. Geophys. Res., 105, 26931-26945, 2000. 